\title{
QUALITY, NOT QUANTITY: AN ANALYSIS OF CONFIDENTIAL SETTLEMENTS AND LITIGANTS' ECONOMIC INCENTIVES
}

\author{
ALISON LOTHES ${ }^{\dagger}$ \\ INTRODUCTION
}

The recent rise of "sunshine" legislation, which prohibits or reduces secret settlements of civil lawsuits, highlights public unease with confidential settlements. Recurring, highly publicized, dangerous events expose the costs of confidentiality: the Bridgestone/Firestone tire scandal and the Catholic Church sex abuse scandal are the most recent. ${ }^{1}$ Litigation regarding the Dalkon Shield, the Ford Pinto, and

\footnotetext{
† B.A. 2001 Dartmouth College; J.D. candidate 2006 University of Pennsylvania. I am grateful to Professors Jason Johnston and Catherine Struve for their insightful advice throughout the process of developing this Comment. I'd also like to thank Michael Ross, Morgan Taylor and the editors at the University of Pennsylvania Law Review whose hard work was invaluable. Lastly, I thank my family for their continuous support of my academic studies, in particular Edward Dabuzhsky for his unending encouragement, patience, and optimism.

1 See Martha Neil, Confidential Settlements Scrutinized, A.B.A. J., July 2002, at 20, 22 (noting that plaintiffs in recent lawsuits against Bridgestone and Catholic Church dioceses contended that the defendants' respective secret settlements perpetuated injuries resulting from product defects and sexual abuse); Thomas A. Fogarty, Can Courts' Cloak of Secrecy Be Deadly?, USA TODAY, Oct. 16, 2000, at 1B (finding that, in approving secret settlements with Firestone, judges subordinated the public interest in order to compensate the injured plaintiffs); Michael McCauley, Court Secrecy Threatens Public Safety, SAN Diego UNION-TRIB., June 6, 2001, at B-9 (condemning an estimated 100 secret settlements in the Ford Explorer/Bridgestone cases as contributing to 148 deaths and 525 injuries due to tread separation). Another example is the automobile industry's tactic of secretly settling product liability cases. See Anne Belli, Ford Resists Release of Escort Documents, DALlas MORNING NeWS, Feb. 13, 1993, at 2F (chronicling a dispute over access to confidential settlement documents regarding an ignition system failure); 48 Hours: Hidden Danger?; Controversy Over Faulty Door Latches in Older GM Cars (CBS television broadcast Dec. 12, 1996) (investigating General Motors' ("GM") repeated secret settlements of lawsuits regarding a door latch problem). Secret settlements of lawsuits pertaining to human health are not limited to the automotive industry. See, e.g., Mark Skertic, BP Amoco Cancer Payouts to Stay Secret, CHI. Sun-Times, Mar. 21, 2000, at 1 (discussing BP Amoco's secret financial settlements with plaintiffs claiming to have developed rare brain tumors from working in the company's labs); Mark Skertic, In One Case, BP Amoco Settlement to Stay Secret, CHI. Sun-Times, Mar. 30, 2000, at 12 (finding that the judge was unable to ensure that BP Amoco's settlement remained public after
} 
other consumer products or environmental toxins has brought to public attention cases of businesses keeping dangerous secrets. ${ }^{2}$ With the increased prevalence of state sunshine laws, it now seems that courts and the public have had enough.

This topic typically engenders normative and theoretical discussions of confidentiality in general. Usually, authors try to determine whether the courts should be private dispute resolution centers or public truth-seeking services. In this Comment, I will address these ideas as background in order to familiarize the reader with the basic arguments on both sides. I will then discuss how the current regime governing confidential settlements of judicial discretion has failed to recognize and address the real problem underlying confidentiality provisions: the divergence between societal and individual costs and benefits created by litigation. In order to resolve the confidentiality debate, we need to understand the incentives of litigants and how confidentiality provisions affect those incentives in order to align them with societal goals.

Currently, two competing frameworks predict the economic costs and benefits secret settlements generate for society. These frameworks generate opposite recommendations: one suggests a regime allowing confidential settlements will be more efficient, while the other suggests a regime restricting such settlements will be more efficient. In this Comment, I will reconcile these two frameworks and argue that all open settlements are not created equal because of the different types of information they may contain. The information contained in some open settlements provides the valuable benefits of deterring

plaintiffs dropped charges). For an extensive discussion of dangers posed to society by secret settlements, see the four-part series in The Washington Post, entitled "Public Courts, Private Justice": Elsa Walsh \& Benjamin Weiser, Court Secrecy Masks Safety Issues, WASH. POST, Oct. 23, 1988, at A1 (investigating GM's legal tactic of using secret settlements to withhold automobile safety information from the public); Elsa Walsh \& Benjamin Weiser, Hundreds of Cases Shrouded in Secrecy, WASH. POST, Oct. 24, 1988, at A1 (reporting the use of secrecy orders to conceal public safety hazards in a variety of industries); Benjamin Weiser \& Elsa Walsh, Drug Firm's Strategy: Avoid Trial, Ask Secrecy, WASH. POST, Oct. 25, 1988, at A1 (detailing the public hazards of confidentiality agreements in the pharmaceutical industry); Benjamin Weiser \& Elsa Walsh, Secret Filing, Settlement Hide Surgeon's Record, WASH. POST, Oct. 26, 1988, at A1 (investigating the effects of secret settlements that prevent public disclosure of medical malpractice).

${ }^{2}$ See David Luban, Settlements and the Erosion of the Public Realm, 83 GEO. L.J. 2619, 2624 n.27 (1995) (discussing an account that details the secret terms of the Dalkon Shield settlement); Heather Waldbeser \& Heather DeGrave, Note, A Plaintiff's Lawyer's Dilemma: The Ethics of Entering a Confidential Settlement, 16 GEO. J. LEGAL ETHICS 815, 819 (2003) (stating that secret settlements delayed the public's learning of, among other hazardous products, exploding gas tanks in the Ford Pinto). 
wrongdoers and compensating victims, while other information tends to encourage nuisance suits. Thus, by comparing how types of information incentivize future litigants, I provide my own explanation of when society benefits from confidentiality. Lastly, I apply my explanation and conclusions to evaluate existing laws that prohibit physicians from confidentially settling malpractice suits. While the debate on confidentiality provisions has focused primarily on how much sunshine is required, I will explain that the more appropriate question is what kind of sunshine is required.

\section{BACKGROUND}

Courts may sanction confidentiality in three ways: protective orders on discovery materials, sealing orders on court records, or confidentiality provisions in settlement agreements. I focus exclusively on confidentiality provisions in settlement agreements. These are especially complicated because they are (1) private contractual agreements between the parties in which the court has a less significant role, and (2) final documents which terminate litigation and present significant cost savings to the courts.

Secret settlements can occur in several ways. First, the parties may come to an agreement during the litigation process and ask the judge to approve the settlement and its confidentiality, essentially creating a court order of secrecy. Alternatively, the parties may make the secret settlement contingent on the plaintiff dismissing the lawsuit and dropping the case against the defendant. In this scenario, the court generally has no control over the agreement, as the parties settle out of court.

Settlement and confidentiality have their proponents and opponents. I will summarize below the main advantages, disadvantages, and theoretical underpinnings of each school.

\section{A. Anti-Confidentiality}

Against Settlement by Owen M. Fiss is the classic article condemning settlement. ${ }^{3}$ Although Fiss's article focuses on settlements in general rather than confidentiality provisions, his criticisms are relevant to confidential settlements as well as open ones. He argues that settlements often involve imbalances of power between the negotiating parties, and are thus a result of coercion rather than an exercise of free

\footnotetext{
${ }^{3}$ Owen M. Fiss, Against Settlement, 93 Yale L.J. 1073 (1984).
} 
will. ${ }^{4}$ Fiss argues that the imbalance of power forces the stereotypically poor plaintiff to settle because she is at an informational disadvantage, prefers accelerated payment (because a lesser, immediate settlement payout may be worth more than a larger, delayed payout), and seeks to avoid litigation costs. ${ }^{5}$ In this view, since the confidentiality provision is part of the agreement, it is a result of a flawed process like any other portion of the agreement. Such a process argument weighs against confidentiality.

Fiss also claims that while litigation and court adjudication achieve the dual goals of justice and peace, settlement can only satisfy the latter. $^{6}$ Referring to Brown v. Board of Education, he powerfully concludes that " $[\mathrm{t}]$ he settlement of a school suit might secure the peace, but not racial equality." Adjudication, in his view, is critical to exposing tough issues and forcing society to be self-aware and self-critical. ${ }^{8}$ This argument is especially compelling in areas of civil rights and constitutional law, where litigation can serve as a tool to develop and explicate the law.

Confidentiality provisions pose additional problems beyond Fiss's criticisms of the general settlement process, as the public may have an interest in the content of the litigation. Open litigation has often divulged health and safety hazards. Conversely, secrecy threatens to perpetuate unexposed danger, imposing costs upon others who are unaware of that danger. ${ }^{9}$ Public access advocates argue that the pub-

${ }^{4}$ See id. at 1076 ("[S] ettlement is also a function of the resources available to each party to finance the litigation, and those resources are frequently distributed unequally.").

${ }^{5}$ Id. But see Alan E. Garfield, Promises of Silence: Contract Law and Freedom of Speech, 83 CORNELL L. REV. 261, 286 (1998) (discussing blackmail as a potential result of power imbalances, indicating that the plaintiff may be in the position of greater power, extracting payment from the defendant by threatening disclosure). For a discussion of the potential moral justification of blackmail, see Mitchell N. Berman, The Evidentiary Theory of Blackmail: Taking Motives Seriously, 65 U. CHI. L. REV. 795, 864 (1998) (discussing the example of "a gay rights organization [that] threatens to out a closeted gay Congressman unless he abandons his support for anti-gay legislation" as potentially morally justified blackmail).

${ }^{6}$ See Fiss, supra note 3, at 1085 (arguing that the courts' "job is not to maximize the ends of private parties, nor simply to secure the peace, but to explicate and give force to the values embodied in authoritative texts such as the Constitution[;] . . to interpret those values and to bring reality into accord with them").

Id. at 1085 (addressing Brown v. Bd. of Educ., 349 U.S. 294 (1955)).

${ }^{8}$ See id. at 1086 (arguing that settlement allows society to "mask[] its basic contradictions").

${ }^{9}$ See Luban, supra note 2, at 2653 (summarizing the general problem of secret settlements as "perpetuating avertable public hazards . . . by passing on costs to third parties not at the table"). 
lic has a right to information that divulges a risk to the public; the private parties' rights to confidentiality are subordinate to the public's interest in safety. ${ }^{10}$

David Luban has refined Fiss's position attacking settlements by stating that while some settlements are problematic, ${ }^{11}$ secret settlements are especially so. ${ }^{12}$ Luban articulates Fiss's arguments as a "public life" perspective. ${ }^{13}$ Under this view, the court itself is a public institution, with a public-service function independent of being merely a "servant" of the parties in its courtroom: ${ }^{14}$ that function is typically to "give meaning to our public values." 15 Thus, if courts are "instruments of the public" and judges are "guardians of the public," the court may have a duty to prevent a secret settlement that risks the health or welfare of the public, or restricts vital public debate, regardless of the private interests of the litigants. ${ }^{16}$ Such an expansive view of judicial function is central to the anti-confidentiality viewpoint.

Ethical problems with confidentiality are not restricted to the court's duties to the public. Plaintiffs' lawyers may face a dilemma when defendants' lawyers propose a secret settlement that is lucrative for plaintiffs but potentially hazardous to the public. In fact, plain-

${ }^{10}$ See David A. Dana \& Susan P. Koniak, Secret Settlements and Practice Restrictions Aid Lawyer Cartels and Cause Other Harms, 2003 U. ILL. L. REV. 1217, 1219 (stating that secret settlements require the plaintiff to sell the public's access rights to information that the plaintiff has no "legitimate right to sell," nor any "legitimate property right").

${ }^{11}$ See Luban, supra note 2, at 2647 (claiming that settlement can also fulfill values central to Fiss's vision by contributing to "openness, political transparency, legal justice, and public-good creation").

${ }^{12}$ See id. at 2648-49 (finding that openness is "at the core of democratic political morality" and that secret settlements are therefore "an unacceptable area of exceptions to democratic publicity").

${ }^{13}$ See id. at 2633-35 (summarizing the public life conception, derived from the ancient Greek emphasis on political participation, as eventually coming to mean that "all adjudications are public in significance").

${ }^{14}$ See Judith Resnik, Whose Judgment? Vacating Judgments, Preferences for Settlement, and the Role of Adjudication at the Close of the Twentieth Century, 41 UCLA L. REV. 1471, 1527 (1994) (discussing the "meaning of courts as institutions" and noting that courts "are not 'servants' of the parties").

${ }^{15}$ Owen M. Fiss, The Supreme Court, 1978 Term-Foreword: The Forms of Justice, 93 HARV. L. REV. 1, 2 (1979); accord, Laurie Kratky Dore, Secrecy by Consent: The Use and Limits of Confidentiality in the Pursuit of Settlement, 74 Notre Dame L. Rev. 283, 296 (1999) (describing the function of the court as a "vehicle for public discourse, for the explication of public values, and for the refinement or improvement of the law"); Luban, supra note 2, at 2634 (stating that the public life conception finds that laws realize values in a "kind of public morality").

${ }^{16}$ See Resnik, supra note 14, at 1527 (arguing that courts have a duty of accountability to the public). 
tiffs' lawyers have supported bans on confidential settlements in order to avoid this difficult ethical dilemma. ${ }^{17}$ As will be discussed below, ${ }^{18}$ some legal experts propose an ethical rule prohibiting participation in any agreement that would restrict the availability of public information implicating a substantial danger to public health or safety. ${ }^{19}$

\section{B. Pro-Confidentiality}

On the other hand, pro-confidentiality scholars emphasize the costs savings from settled cases and the importance of litigants' rights to privacy and autonomy. Arthur Miller and Richard Marcus are probably the most prominent advocates of secret settlements. ${ }^{20}$ While Fiss finds the negotiating process to be inherently flawed, prosettlement and pro-confidentiality scholars view settlement as a classic example of the freedom to contract. These scholars argue that the litigant's autonomy is not only an important right, but also a traditional tenet of our civil justice system. ${ }^{21}$ The "party-initiated, partycentered, and party-controlled system regards litigant autonomy as a value in itself" and "installs preferences of the parties as the best measure of fairness available." ${ }^{22}$ In this school of thought, settlement itself is considered an individual right ${ }^{23}$ as well as the most efficient solution to disputes. ${ }^{24}$

${ }^{17}$ See Jean Hoefer Toal \& Bratton Riley, The New Role of Secret Settlements in the South Carolina Justice System, 55 S.C. L. REV. 761, 768 (2004) (stating that the South Carolina Trial Lawyers' Association supported a proposed rule restricting secrecy because "it would unshackle the plaintiff's lawyer from being forced to sign a confidential settlement agreement to honor his obligation to obtain a fair settlement on behalf of his client while cognizant that the document conceals a potential public harm").

${ }^{18}$ See infra text accompanying notes 61-62.

${ }^{19}$ See Richard A. Zitrin, The Laudable South Carolina Court Rules Must be Broadened, 55 S.C. L. REV. 883 app. at 906 (2004) (proposing an ethics rule for South Carolina prohibiting a lawyer from participating in a settlement that would restrict public access to information that the lawyer reasonably believes implicates directly a substantial danger to public health or safety).

${ }^{20}$ See, e.g., Richard L. Marcus, The Discovery Confidentiality Controversy, 1991 U. ILL. L. Rev. 457; Arthur R. Miller, Confidentiality, Protective Orders, and Public Access to the Courts, 105 HARV. L. REV. 427 (1991).

${ }^{21}$ See Dore, supra note 15, at 297-98 (stating that the civil justice system was originally designed to grant parties maximum control over the litigation process, with minimal judicial interference).

${ }^{22}$ Id. at 298 (quoting Resnik, supra note 14, at 1539).

${ }^{23}$ This argument harkens back to Lochner-era protection of individual property rights. Lochner v. New York, 198 U.S. 45 (1905). It is fairly clear that a negotiated settlement is a contract, and that parties have a right to bargain in reaching a settlement agreement just as with any other agreement. See Miller, supra note 20, at 486 (ac- 
In addition, Arthur Miller provides crucial arguments for protecting confidentiality on account of the information content. He emphatically contends that "[1]itigants do not give up their privacy rights simply because they have walked, voluntarily or involuntarily, through the courthouse door." ${ }^{25}$ In his view, litigants have privacy rights and property rights in keeping certain information confidential; these rights are seriously threatened by the public's compulsion for voyeurism. ${ }^{26}$ Privacy and property rights may be valuable to both the individual rights-possessor and society, as they incentivize efficient business. $^{27}$ Lastly, Miller questions the assumption that the types of confidential information at issue are likely to be directly relevant to public health and welfare concerns. ${ }^{28}$

Pro-confidentiality scholars restrict the judicial function to resolving private party disputes. Luban describes the "problem-solving conception" of the judicial function as one that is rooted in distrust of interfering on behalf of the public interest. ${ }^{29}$ In sharp contrast to the "public-life" scholars, ${ }^{30}$ Richard Marcus argues vehemently that the court has no role in shaping public values. ${ }^{31}$ In addition, Miller also argues that the administrative branch may be better suited than the judicial branch to be a public watchdog. ${ }^{32}$ Thus, according to Miller

knowledging that "a court should honor confidentialities that are bargained-for elements of settlement agreements").

${ }^{24}$ Negotiation between parties is simply another form of efficient bargaining, according to the famous theorem developed by Ronald Coase. See generally R.H. Coase, The Problem of Social Cost, 3 J.L. \& ECON. 1 (1960).

${ }^{25}$ Miller, supra note 20, at 466.

${ }^{26}$ See id. at 466-74 (predicting that mandatory disclosure rules could threaten individual constitutional privacy rights as well as interfere with efficient and economically valuable property rights).

${ }^{27}$ See id. at 468 (referring to John Locke's notion of property rights as incentives to productivity and critical to individual freedom, while recognizing their role in protecting innovation and competition).

${ }^{28}$ See id. at 478-82 (questioning whether confidentiality in the courts has become a scapegoat for information failures in our society).

${ }^{29}$ See Luban, supra note 2, at 2632-33 (concluding that the "problem-solving conception" identifies "public" with "government," places human freedom in the private sphere, and mistrusts government intervention).

${ }^{30}$ See supra Part I.A.

31 See Marcus, supra note 20, at 469-70 (arguing that the courts were created to resolve disputes but not to "give expression to []public values[]").

${ }^{32}$ See Miller, supra note 20, at 488 (noting that Congress has endowed federal regulatory agencies with quality control powers while judges may lack the scientific and technical expertise to assess complex health and safety matters). But see Jack B. Weinstein, Secrecy in Civil Trials: Some Tentative Views, 9 J.L. \& POL'y 53, 58-59 (2000) (suggesting that executive agencies may not be sufficiently performing their assigned 
and Marcus, public funding does not alter the court's fundamental mission to serve private parties.

Lastly, Miller reiterates the common argument that confidentiality preserves court resources by efficiently promoting settlement. ${ }^{33}$ Settlement conserves court and party resources by allowing cooperative private solutions. Several scholars have concluded that confidentiality is absolutely necessary to settlement in some cases, establishing that confidentiality itself may contribute to a conservation of judicial resources. ${ }^{34}$ As will be explored extensively below, ${ }^{35}$ Miller also argues that confidential settlements prevent excessive nuisance suits, resulting in additional savings. ${ }^{36}$

\section{The Economic Rationale}

The above discussion, although not an exhaustive analysis of confidential settlements, indicates the prevailing focus on the conflict between individual and public interests. Steven Shavell's powerful article, The Fundamental Divergence Between the Private and the Social Motive To Use the Legal System, illustrates the root of the problem in economic terms: the costs and benefits of the legal system to the private individual and to the general public diverge. ${ }^{37}$ Shavell first notes that the societal costs of litigation, including to the court, judge, and defendant, are collectively greater than the individual costs of litigation to the plaintiff. $^{38}$ A plaintiff might naturally ignore social costs when deciding to litigate, but her decision to litigate will inevitably impose sig-

regulatory functions and implying that settlement agreements provide transparency not available from federal agencies).

33 See Miller, supra note 20, at 487-88 (noting that the court system is already overwhelmed with more demands on its time than it can possibly handle, and should not be saddled with a "court-administered Freedom of Information Act").

${ }^{34}$ See Luban, supra note 2, at 2656 ("Some settlements will break down if secrecy is unavailable ....").

35 See infra Part III.B.

${ }^{36}$ Miller, supra note 20 , at 485 ("[C] onfidentiality ensures that the settlement amount will not be used to encourage the commencement of other lawsuits that never would have been brought or as unfair leverage to extract a similar payment in subsequent suits that may be meritless.").

3726 J. LEGAL STUD. 575 (1997). For further discussion of welfare economics and the incentives to litigate, see generally Louis Kaplow \& Steven Shavell, Fairmess Versus Welfare, 114 HARV. L. REV. 961 (2001).

${ }^{38}$ Shavell, supra note 37, at 577-78. Professor Patricia Danzon has noted this problem in medical malpractice cases, describing the costs imposed on the public, on other litigants waiting to be heard, and on the defendant. PATRICIA M. DANZON, MEDICAL MAlPRACTICE: Theory, Evidence, AND Public POLICY 192 (1985). 
nificant costs on others. ${ }^{39}$ Thus, from a cost standpoint, there may be an excessive incentive to litigate because the plaintiff has only accounted for her personal costs and not for all of the costs imposed on the general public. Shavell also concludes that there is often no relation between a lawsuit's social benefit and private benefit, as the plaintiff is usually driven by a need for compensation, but is unconcerned with the general social goals of deterrence. ${ }^{40}$ Therefore, it becomes obvious that the social costs and benefits of litigation will most likely not align with plaintiffs' incentives. Unfortunately, it is the plaintiff who ultimately decides whether to litigate or to settle. Thus, depending on whether the plaintiff's net benefit exceeds society's net benefit, there will be an excessive or inadequate incentive to bring suit. ${ }^{41}$

Although Shavell's theorem does not specifically address confidentiality provisions, the application of the theorem to such provisions leads to the belief that a confidentiality provision will typically have much greater individual benefit than social benefit. ${ }^{42}$ On one end of the spectrum, if the public has no interest in the topic of litigation, the public and individual interests align: settlement is cheapest for the public and most lucrative for the plaintiff. As the potential for deterrence grows, however, so does the social benefit arising from keeping the settlement open. At the same time, defendants will have greater incentive to settle secretly, offering more money to the plaintiff to preserve defendants' reputation and prevent further lawsuits. When "the plaintiff's return from suit is less than its deterrent effect," the plaintiff and defendant will likely prefer confidential settlementto society's detriment. ${ }^{43}$ Thus, confidentiality provisions exacerbate the underlying problem of diverging costs and benefits when the defendant is willing to pay more because the information would expose her to even greater liability.

\footnotetext{
${ }^{39}$ See Shavell, supra note 37 , at 577-78 (explaining that when a plaintiff assesses the costs of her potential suit, she does not consider costs imposed on defendants and courts).

${ }^{40} I d$. at 578 .

${ }^{41} I d$.

${ }^{42}$ See, e.g., Garfield, supra note 5, at 332 (acknowledging that a plaintiff can extract payment for confidentiality).

${ }^{43}$ Shavell, supra note 37 , at 578.
} 


\section{CURRENT APPROACHES TO APPLYING SECRECY AND THEIR DOWNFALLS}

As illustrated above, confidentiality provisions present complex problems to the judicial system. The public has an interest in settling disputes efficiently, maintaining the correct amount of litigation, and deterring wrongful conduct. Meanwhile, private interests in compensation and contractual autonomy are fundamental to our sense of justice. Who should balance the public and private interests to decide whether confidentiality is appropriate in a particular situation? There are several possible approaches, the most popular being judicial discretion exercised on a case-by-case basis, and the least popular being an ethical obligation on plaintiffs' lawyers. I will argue that the current methods and proposals are not likely to succeed because they do not correctly address the underlying problem of diverging incentives.

\section{A. Judicial Discretion}

There is no federal rule specifically addressing secret settlements. In general, federal judges may issue a protective order to restrict access to documents if there is "good cause" and the parties' interest in confidentiality outweighs any other harm. ${ }^{44}$ Many districts have their own local rules pertaining to confidential settlements. Forty-nine districts have local rules concerning sealing court records in civil cases, fourteen of which pose no limits to sealing. ${ }^{45}$ Of the remaining thirtytwo districts with local rules relevant to either the grounds for sealing or the duration of sealing, twelve require the judge to find "good cause" prior to sealing. ${ }^{46}$ Thus, a case-by-case judicial discretion rule seems to be the norm; parties can ask the court to seal the case, hiding it from public view, and leaving it up to the judge to decide. Such reliance on judicial discretion has failed, as evidenced by the courtcondoned secret settlements regarding Catholic priests' sexual abuse and Bridgestone/Firestone's tire problem. ${ }^{47}$ In fact, some judges have

${ }^{44}$ FED. R. CIV. P. 26(c) (“[T] he court ... may make any order which justice requires to protect a party or person from annoyance, embarrassment, oppression, or undue burden or expense ....").

${ }^{45}$ Fed. Judicial Ctr., Sealed Settlement Agreements in Federal District COURT 2 (2004), http://www.fjc.gov (follow "Recent Publications" hyperlink, then "Sealed Settlement Agreements in Federal District Court" hyperlink).

${ }^{46} I d$.

${ }^{47}$ See Neil, supra note 1, at 20, 22 (noting questions about the propriety of secret settlements involving Bridgestone/Firestone and the Catholic Church, which are seen by many as having sacrificed the public interest for the interests of private parties); see 
admitted that they are extremely prone to rubber stamping any settlement agreement in the interest of clearing their dockets. ${ }^{48}$

One particularly invidious type of private settlement is exemplified by a Prozac case handled by Kentucky Judge John Potter. ${ }^{49}$ The plaintiff and defendant came to a secret agreement during trial: in return for agreeing not to introduce damaging evidence, the plaintiff would be assured some amount of payment from the defendant, even if the jury found for the defendant. ${ }^{50}$ The agreement "assured the plaintiffs of at least X dollars while capping Lilly's exposure at $\$ 1.75 \mathrm{X} \ldots$. . [and] was structured as it was so that Lilly would be able to point to a defense verdict as an exoneration of Prozac." ${ }^{51}$ The agreement worked: the jury found Eli Lilly to be free from fault, which Eli Lilly happily broadcast to the public as proof of Prozac's safety and effectiveness. $^{52}$

The agreement reached in this case is a close corollary to "Mary Carter" agreements, where one contracting defendant assures a plaintiff payment, decreasing that defendant's liability in proportion to a corresponding increase in a non-agreeing defendant's liability. ${ }^{53}$ Mary

also Walsh \& Weiser, Hundreds of Cases Shrouded in Secrecy, supra note 1, at A1 (suggesting that judges may ignore their duty to the public because they "have approved secrecy orders in lawsuits involving allegations of misconduct by doctors and lawyers, safety hazards in public facilities and products, and race and sex discrimination").

${ }^{48}$ See Joseph F. Anderson Jr., Hidden from the Public by Order of the Court: The Case Against Government-Enforced Secrecy, 55 S.C. L. REV. 711, 712-13, 716, 729-30 (2004) (detailing his own and other judges' admissions that they have approved secret settlements under pressure stemming from an extreme caseload); Luban, supra note 2, at 2650 (concluding that among the two hundred sealed records cases between 1980 and 1987 in Dallas County, one finds several examples of product defects that have affected public safety, including Dow Corning's silicone breast implants, Ford and General Motors pickup trucks, and Upjohn's sleeping pill Halcion); Richard A. Posner, What Do Judges and Justices Maximize? (The Same Thing Everybody Else Does), 3 SuP. CT. ECON. REV. 1, 1-7 (1993) (arguing that judges are not immune from reacting rationally to "ordinary incentives," such as docket pressure).

${ }^{49}$ See William H. Fortune, A Proposal to Require Lawyers to Disclose Information About Procedural Matters, 87 Ky. L.J. 1099, 1101-05 (1999) (describing Judge Potter's actions and citing Winkler v. Eli Lilly E Co., 101 F.3d 1196 (7th Cir. 1996) and Potter v. Eli Lilly E̊ Co., 926 S.W.2d 449 (Ky. 1996)).

${ }^{50} I d$. at 1102 .

${ }^{51} I d$.

${ }^{52}$ See id. at 1105 (quoting press releases demonstrating the company's use of the verdict as exoneration for the drug). Ultimately, Judge Potter pursued his suspicions that the judgment did not "accurately reflect the truth," and moved sua sponte to correct the judgment, ultimately appealing to the Kentucky Supreme Court. Id. at 1107 (citing Potter, 926 S.W.2d at 453).

53 "Mary Carter" agreements earned their name from the seminal case in which such a deal was brokered, Booth v. Mary Carter Paint Co., 202 So. 2 d 8 (Fla. Dist. Ct. App. 
Carter agreements suggest that judges are not able to adequately control secret settlements in their courtrooms, much less those that never reach the courtroom.

To address these many invidious triggers of confidentiality, a few states have enacted "sunshine" reforms which create a statutory presumption of openness. ${ }^{54}$ Florida passed the first such reform in 1990 with the Sunshine in Litigation Act, providing that confidential agreements which conceal a public hazard or information relating to a public hazard may not be enforced because they are contrary to public policy. ${ }^{55}$ Texas passed reforms in 1990 as well, establishing Texas Rule of Civil Procedure 76(a), which states that court records are presumed to be open to the general public and allows them to be sealed in only limited circumstances. ${ }^{56}$ Arkansas, Washington, and Louisiana have also passed some type of settlement reform. ${ }^{57}$

These reforms have not solved the problem. In some cases, subsequent judicial interpretation of the reform statute has weakened the law. ${ }^{58}$ Broadly, the crux of the issue is that, regardless of whether the presumption is for openness or confidentiality, the laws are always prone to judicial discretion in application; judges can still allow secrecy when they see fit.

Finally, an unresolved problem remains: secret settlements outside of the courtroom may be made without any court scrutiny. ${ }^{59}$ Private se-

1967). See Fortune, supra note 49, at 1121 (discussing the confusion that Mary Carter agreements cause regarding parties' true intentions); see also id. at $1121 \mathrm{n} .140$ (citing numerous sources that discuss Mary Carter agreements).

${ }^{54}$ See FED. JUdiCIAL CTR., supra note 45 , at 5 (summarizing state statutes and rules regarding the confidentiality of court proceedings).

${ }^{55}$ FLA. STAT. ANN. $\$ 69.081$ (4) (West 2004).

${ }^{56}$ TEX. R. CIV. P. 76(a).

${ }^{57}$ See Zitrin, supra note 19, at 893-95 (referring to, inter alia, ARK. CODE ANN. § 1655-122 (Supp. 2003), WASH. REv. CODE ANN. § 4.24.611 (West Supp. 2004), and LA. Code Civ. Proc. ANN. art. 1426(D) (Supp. 2004)).

${ }^{58}$ See id. at 891 ("Unfortunately, the application of these rules and statutes has been undercut, sometimes severely, . . . by subsequent court decisions interpreting the regulation.").

${ }^{59}$ See Dore, supra note 15, at 387 (finding that even in the face of sunshine laws, "litigants generally possess wide latitude to contract for settlement confidentiality" because they can simply file a stipulation of dismissal with the court and sign a private agreement); see also Garfield, supra note 5, at 263-67 (arguing that contracts of silence-private contracts entirely outside the courts requiring confidentiality-have been largely unregulated and untouched by precedent). California has tried to address contracts of silence through several bills, but none has passed. See, e.g., S.B. 11, 2000 S., Reg. Sess. (Cal. 2001) (attempting to legislate against contracts of silence); Assemb. B. 36, 2001 Gen. Assemb., Reg. Sess. (Cal. 2001) (same). See generally Michael K. Brown \& Lisa M. Baird, Business' Privacy and Property Rights Threatened in California, 
cret settlements might occur before the suit is even filed. Such agreements are prone to the same problems as court-sanctioned ones: they suppress information about harmful products, criminal or tortious conduct, or other dangers to public safety. ${ }^{60}$

\section{B. Lawyers Decide}

Another option is for the lawyers involved to regulate secret settlements by refusing to engage in negotiations or to represent their client in signing the agreement. This option has been advocated by legal ethicist Richard Zitrin and other ethicists who ask lawyers to instate a high ethical standard of behavior. ${ }^{61}$ Zitrin has been the most outspoken advocate of this approach, formulating a model ethics rule prohibiting lawyers from signing agreements that harm third parties. ${ }^{62}$ This rule is targeted and specific to the problem: confidentiality is not per se outlawed, but rather is only prohibited when the lawyer reasonably believes the information could be relevant to others' safety. ${ }^{63}$ Such a rule would require lawyers to disclose the policy to their client at the outset of their representation.

Others have also endorsed the notion that lawyers should help regulate secret settlements, proposing that "attorneys have an obligation to reveal any secret arrangement which alters the positions of the parties." ${ }^{64}$ Although this argument emphasizes the judge's need for an honest understanding of the litigants' positions rather than preventing harm to third parties, the basic foundation of the position is the same: an ethical obligation gives the lawyer "an excuse to do the right thing." 65

Some argue that the duty of "zealous advocacy" inherently prohibits the lawyer from interfering with the plaintiff's interest in obtaining

LEGAL BACKGROUNDER, Feb. 23, 2001, at 1, 2-4 (arguing that such bills are egregious and unnecessary infringements on privacy and property rights).

${ }^{60}$ See Garfield, supra note 5, at 275 (analyzing the legal basis and criticism against "contracts of silence").

${ }^{61}$ See Zitrin, supra note 19, at 904 (arguing that rules of professional ethics should supplement court rules and statutes governing secret agreements); see also RICHARD ZITRIN \& CAROL M. LANGFORD, THE MORAL COMPASS OF THE AMERICAN LAWYER 183208 (1999) (citing a number of products liability cases in which lawyers were uniquely positioned to prevent public harm).

${ }^{62}$ Zitrin, supra note 19 , at 905-06.

${ }^{63} I d$.

${ }^{64}$ Fortune, supra note 49, at 1121.

${ }^{65} I d$. at 1123. 
a lucrative settlement. ${ }^{66}$ Furthermore, a lawyer has her own interests at stake as well: lawyers who operate with a contingency fee may be biased in favor of settlement. Nonetheless, given the present nature of the legal system, it appears that lawyers, in fact, may be in the best position to regulate secret agreements. Scholars have noted that the public trial is no longer the focus of our justice system. ${ }^{67}$ As only four percent of all filed civil cases now proceed to trial, it appears that our judicial system's focus has shifted from trial litigation to pretrial negotiation. ${ }^{68}$ Accordingly, the process seems to be less judge-centered and more lawyer-centered. ${ }^{69}$ It seems appropriate, therefore, to rest the burden of regulating secret settlements on those most involved with the negotiation: the lawyers. This could also help to solve the problem of private secret settlements, which would still require an attorney, even if they are outside the judge's purview.

Although ethical regulations are laudable and potentially effective (at least in part), they are not enthusiastically endorsed. ${ }^{70}$ Several scholars claim that a lawyer has a duty to her client only; any ethical

${ }^{66}$ See David Luban, Limiting Secret Settlements by Law, 2 J. INST. STUD. LEGAL ETHICS 125, 128 (1999) (arguing that Zitrin's proposed ethical rule prevents lawyers from compassionately advocating for their clients, encourages clients to make an "end-run" around the lawyers, and creates an incentive for lawyers to negotiate the settlement early in the process, before it is possible to form a "reasonable belief" that "public health or safety" is in peril). But see Luban, supra note 2, at 2624 (noting that "[t]he public-good character of attorney skills" has been acknowledged in professional ethics codes, which restrict lawyer-buyout agreements).

${ }^{67}$ See Dore, supra note 15, at 288 (noting that decisions on the merits are becoming increasingly rare as pretrial motions, discovery, and settlement negotiations absorb most of a typical lawyer's and court's time and resources).

${ }^{68}$ Id.; see also Marc Galanter \& Mia Cahill, "Most Cases Settle": Judicial Promotion and Regulation of Settlements, 46 STAN. L. REV. 1339, 1339-42 (1994) (arguing that settlements have become the dominant method of case resolution and should be assessed with a critical eye as a result).

${ }^{69}$ See Stephen Yeazell, The Misunderstood Consequences of Modern Civil Process, 1994 WIS. L. REV. 631, 632-39, 646-48 (examining the dramatic reforms in civil procedure, which greatly increased pre-trial options and therefore shifted the power balance from judges to lawyers). Adversarial systems may be more prone to be lawyer-centered with a strict division of pre-trial and trial procedure, whereas the civil law system is more judge-centered with a continuous trial process. For a comparative discussion of the two, see generally John H. Langbein, The German Advantage in Civil Procedure, 52 U. CHI. L. REV. 823 (1985), which argues that the shortcomings of the American adversarial system are addressed by the civil law system of Germany.

${ }^{70}$ See Dana \& Koniak, supra note 10, at 1217 n.1 (reporting that the Ethics 2000 Commission rejected such regulations because state legislatures are better equipped for such changes, and the ethical regulations of lawyers would put pro se parties at an advantage). The authors, however, go on to dispute the reasoning of the Commission and to argue that both ethics rules and criminal and civil laws ought to curtail harmful secret settlements. Id. at 1226-41. 
regulations that create a duty to the public are thus conflicts of interest. $^{71}$ The lawyer's obligation to act in the best interests of her client may be best fulfilled by a secret settlement. Even Luban, who has powerfully condemned secret settlements, acknowledges that "secret settlements may be the only way that a weak plaintiff who has suffered serious harm can obtain compensation." ${ }^{72}$ Secret settlements may cost others (the public and subsequent plaintiffs), but the lawyer can reply that she must defend her client's right to compensation. In sum, an ethical obligation is a good start, but will not solve the problem entirely.

\section{Comparison}

Neither the judge-centered nor the lawyer-centered approach to regulating secret settlements is workable. The incentives in each case do not align. Judges have incentives to reduce their caseload, favoring settlements of cases before them. Further, judges have incentives to dismiss a suit and allow parties to settle out of court, beyond the control of the judge. Meanwhile, a lawyer's incentives are aligned with her client's. In addition, asking the plaintiff to forego a lucrative settlement is difficult and many lawyers would object to such an obligation. Furthermore, secrecy has direct consequences for the lawyer's practice, as the lawyer could be prohibited from representing a client in a suit against the same defendant in the future. ${ }^{73}$ Thus, although an ethical obligation could be at least somewhat effective, it is hard to impose it upon the American adversarial legal system.

Solving this problem therefore requires state legislatures to address the litigants' incentives, rather than relying on either judges or lawyers to regulate themselves by pushing against their personal inter-

\footnotetext{
${ }^{71}$ See Luban, supra note 2, at 2624-25 (stating that lawyers' professional ethics codes generally find that "a lawyer who fails to maximize a client's outcome out of concern for future clients is guilty of a conflict of interest"). One interesting exception to the general rule of zealous advocacy is ethical prohibitions on lawyer-buyout agreements, indicating that lawyers do have a duty to the general public. See id. (finding, in the presence of such prohibitions, a sense that attorney skills become a public good); Dana \& Koniak, supra note 10, at 1218-19 (condemning lawyer-buyout agreements as an impermissible usurpation by the plaintiff of the lawyer's rights).

${ }^{72}$ Luban, supra note 2, at 2657.

${ }^{73}$ See Dana and Koniak, supra note 10, at 1218-19 (asserting that the law should curtail secret settlements and future-practice restrictions, given the "anticompetitive effects" of such practices on the legal market).
} 
ests. $^{74}$ Restricting confidential settlements should not be a result of judges' case-by-case determinations or lawyers' ethical obligations. Instead, we need to create legislation which is tailored to litigants' incentives and matches the public interest. ${ }^{75}$ Optimally, we need to create a regime that generates enough openness to meet the twin goals of compensation and deterrence, while reserving a level of confidentiality that protects defendants' and plaintiffs' rights.

Generally speaking, society benefits by promoting litigation that furthers the goals of tort deterrence and just compensation. Accordingly, the public may have an interest in only certain types of litigation: those where non-party citizens were harmed or threatened to be harmed by the defendants' conduct. Certain industries, such as those involving mass consumer products, healthcare, and transportation, are areas in which litigation is more efficient than settlement because society has a greater interest in deterrence and compensation in these cases. Other areas, such as family law, are generally more appropriate for confidential settlements. Combining Shavell's economic analysis, explained in Part II.C, with the practical analysis in this Part suggests a possible solution of restricting confidentiality in targeted areas, while preserving the possibility of confidentiality for the majority of litigants.

\section{ECONOMIC MODELS AND LITIGANTS' INCENTIVES}

In this Part, I will consider what kind of legislation provides the proper incentives to litigants. I will compare two economic frameworks, each consisting of multiple models that analyze litigant incentives regarding confidential settlements and litigation. The first framework supports an open regime (one which would prohibit confidential settlements), while the second framework supports litigant autonomy and the right to secrecy. After analyzing each framework, I will offer a resolution to the conflict between them.

\footnotetext{
${ }^{74}$ This approach will side-step the issue of judicial discretion, discussed supra, Part II.A, by removing the judge's role in prohibiting or allowing confidential settlements.

${ }^{75}$ There are already examples of statutes that provide incentives to private plaintiffs that correlate with the public interest, such as qui tam actions. See, e.g., Federal False Claims Act, 31 U.S.C. $\$ 3729$ (2000) (allowing private individuals to enforce government fraud claims by filing the suit themselves and sharing in the recovery with the government). For a discussion of qui tam actions and litigation incentives, see generally Jill E. Fisch, Class Action Reform, Qui Tam, and the Role of the Plaintiff, 60 LAW \& CONTEMP. PROBS. 167 (1997).
} 


\section{A. Framework 1}

Openness as Efficient: Increasing the Number of Viable Suits, Thereby Increasing Compensation and Deterrence

"Framework 1" is based on two papers by economists Andrew F. Daughety and Jennifer F. Reinganum. ${ }^{76}$ In their paper entitled Hush Money, Daughety and Reinganum create an incomplete information model in which a plaintiff offers several settlement demands, one of which involves secrecy, to the defendant who must then decide whether and how to settle. ${ }^{77}$ In their model, the plaintiff, $P 1$, will always go to trial when her expected damages exceed her litigation costs. $^{78}$ A future plaintiff, $P 2$, can only learn of the complicity of the defendant, $D$, in $P 1$ 's injury through publicity created by the outcome of P1's lawsuit. ${ }^{79}$ In addition, the model assumes a "weak" correlation between $D$ 's culpability for P1's injury and her culpability for P2's injury. ${ }^{80} \quad$ Daughety and Reinganum construct a reasonable publicity range in which, at one end, $P 2$ learns of $D$ 's culpability through a completed trial; without a trial, $P 2$ has a smaller probability of learning of $D$ 's culpability through open settlement, and a still smaller probability through confidential settlement. ${ }^{81} P 2$ 's chance of learning of $D$ 's culpability is greater than zero for all of these options; that is, even a confidential settlement has some probability of alerting future plaintiffs. ${ }^{82}$

Addressing the other end of the negotiating table, Daughety and Reinganum describe $D$ as being in one of four types of scenarios. These scenarios are created by combining high or low culpability with the existence or lack of a future plaintiff, $P 2$. Each scenario is signified by a "type pair" as $H 1, H O, L 1$, or $L O$, where $H=$ high culpability, $L=$ low culpability, $1=$ potential $P 2$, and $0=$ no potential $P 2{ }^{83}$ Daughety and Reinganum assess whether the parties will prefer unrestricted bar-

\footnotetext{
${ }^{76}$ While not intending to delve into the detailed technical aspects of the papers, I will lay out the foundations and conclusions of the two models.

77 Andrew F. Daughety \& Jennifer F. Reinganum, Hush Money, 30 RAND J. ECON. 661 (1999)

${ }^{78}$ See id. at 665 (stating that a plaintiff will pursue a case if the expected net return is positive).

${ }^{79} \mathrm{Id}$.

${ }^{80}$ See id. at 666 (explaining that this particular model addresses a situation in which $D$ may, though not necessarily, be the source of $P 2$ 's injuries).

${ }^{81} I d$.

${ }^{82} I d$.

${ }^{83} I d$. at $666-67$.
} 
gaining (allowing secrecy) or restricted bargaining (prohibiting secrecy).

Regarding the plaintiffs, Daughety and Reinganum conclude that $P 1$ will always prefer unrestricted bargaining because she can extract a larger offer from $H 1$ or $L 1$ defendants, who fear potential $P 2 \mathrm{~s} .{ }^{84}$ They also conclude that $P 2$ will always prefer restricted bargaining, because this will enable her to obtain enough information to be compensated herself. $^{85}$ Regarding the defendants, Daughety and Reinganum explain that $D$ will vary in their preferences in the four types of scenarios. $^{86}$ Even so, a general point emerges from the model: secret settlements allow $P 1$ to extract hush money at the expense of $P 2{ }^{87}$ Thus, the authors conclude:

[W] hen one party wants to limit the diffusion of information to parties outside of the current negotiation, this provides bargaining power to the other party involved in the current negotiation. This effect is capitalized in a higher payment by the first party to the second, a payment that is frequently financed (implicitly) by the unsuspecting third party. ${ }^{88}$

If one imagines that the public has a general interest in compensating potential future injured plaintiffs, secrecy hurts the public by allowing $P 1$ to benefit from a defendant's fear of future lawsuits. In this situation, $D$ and $P 1$ are generally in favor of secrecy, while the public and $P 2$ are generally not in favor of secrecy.

A second article by Daughety and Reinganum provides a complementary model with similar conclusions: a two-period model, in which the defendant has the opportunity to choose either a confidential regime or an open regime. ${ }^{89}$ According to the model, before Period 1 , the defendant does not necessarily know her future liability. ${ }^{90}$ By Period 2, $D$ has learned, through litigation, of her liability. ${ }^{91}$ At this point, the consumer ( $P 2$ and the public) will most likely be at an "informational disadvantage" if $D$ chose a confidential regime. ${ }^{92}$ Other-

${ }^{84}$ Id. at 672

${ }^{85} \mathrm{Id}$.

${ }^{86} I d$. at $672-73$.

${ }^{87} I d$. at 674

${ }^{88} I d$. (emphasis added).

${ }^{89}$ Andrew F. Daughety \& Jennifer F. Reinganum, Secrecy and Safety 3, 5 (revised September 2003) (unpublished manuscript, on file with the University of Pennsylvania Law Review).

${ }^{90} I d$. Daughety and Reinganum base their model on the paradigm of a product manufacturer whose product quality impacts future liability and sales.

${ }^{91} I d$. at 8-9.

${ }^{92} I d$. at 9 . 
wise, under an open regime, the consumer too would have learned about the defendant's potential liability through litigation.

The model sets up the predicted costs for defendants of both regimes and payoffs for the general consumer (i.e., the public). ${ }^{93}$ Daughety and Reinganum assume that the probability of a suit being viable-that a plaintiff will be able to provide sufficient evidence-is greater in open regimes than in confidential regimes. ${ }^{94}$ The model also assumes that plaintiffs with nonviable cases will not receive compensation from a defendant. ${ }^{95}$ In sum, the model concludes that defendants will prefer an open regime when the fraction of viable suits is not extremely high, because credible self-monitoring in an open regime may cost the defendant less in the long run than repeated confidential payments. ${ }^{96}$ Daughety and Reinganum explain, however, that when the fraction of viable suits becomes too high, the defendant will no longer prefer an open regime because the costs of litigation will have become prohibitive. ${ }^{97}$

In conclusion, Framework 1 views $P 1$ 's lawsuit as a source of valuable information for $P 2$, increasing the number of viable legitimate suits and thus increasing compensation for victims. Openness prevents $P 1$ from extracting extra payment from the defendant, which would have cost $P 2$. It compensates more individuals because more injured plaintiffs are able to gather information for their claim. Even from $D$ 's perspective, openness is financially advantageous. Given that frivolous suits cannot succeed in this framework (a significant assumption), $D$ is not at the mercy of P1's demands, allowing $D$ to settle claims more cheaply. Moreover, openness is in the public interest because it is most efficient. Thus, in this framework, the public's desire for compensation, deterrence, and cost-savings is fulfilled by increasing openness.

${ }^{93}$ Openness costs include the company's fixed costs of auditing while benefits include increased consumer confidence and purchasing. Confidentiality may save on less potential litigation but will create costs through decreased potential sales and increased price of settlement. See id. at 9-10 (analyzing the model under the two regimes).

${ }^{94}$ See id. at 7 (explaining how confidential settlements can prevent access to information that would increase the viability of future suits).

${ }_{95}^{9} I d$.

${ }^{96}$ See id. at 23-24 (determining that a firm would be willing to commit to openness when it does not increase the percentage of viable suits and when the actual cost of monitoring is less than the cost of settlements).

${ }^{97}$ See id. at 25. 


\section{B. Framework 2}

Openness as Inefficient: Increasing the Number of Nuisance Suits, Thereby Increasing Improper Payouts and Costs

"Framework 2" is based primarily on Rosenberg and Shavell's model, which establishes equilibrium strategies of the plaintiff and defendant players based on their incentives. ${ }^{98}$ In their model, openness is costly because it encourages nuisance lawsuits. The model deals exclusively with nonviable nuisance suits-i.e., those without merit. It uses variables to represent the plaintiff's cost of filing a claim, the plaintiff's settlement demand, the defendant's cost of litigation, the plaintiff's cost of litigation, the probability of the plaintiff's success, and the amount of the plaintiff's award by default or trial judgment. ${ }^{99}$ Rosenberg and Shavell "assume that both parties know all these variables"; ${ }^{100}$ essentially, the model assumes completely informed parties.

The model leads to several reasonable predictions. If the plaintiff is unwilling to engage in litigation (if, for example, the cost of litigating is greater than the potential award) but still files a nonviable claim, she may be able to extract the defendant's cost of an initial response through settlement. ${ }^{101}$ I label this situation a "Category 1" suit. Assuming that the defendant's initial response cost is less than the judge's eventual award by default or trial, the defendant can agree to settle and pay any amount below the initial response cost. ${ }^{102}$ As long as the plaintiff's cost of filing a claim is less than the defendant's cost of initial response, the plaintiff has an incentive to file suit. ${ }^{103}$

On the other hand, if the plaintiff is willing to litigate (her cost of litigation is less than the potential award), she may extract an even greater amount from the defendant merely by filing her nonviable suit: the cost of the defendant's litigation plus the probability of success multiplied by the potential award, capping out at just under the

${ }^{98}$ D. Rosenberg \& S. Shavell, A Model in Which Suits Are Brought For Their Nuisance Value, 5 INT'L REV. L. \& ECON. 3, 6 (1985) (describing each party's choice to litigate or settle).

${ }^{99} I d$.

${ }^{100} I d$. Costs and knowledge are critical aspects of settlement. For an analysis of settlement incentives when there is asymmetric information and the possibility of feeshifting, see generally Eric Talley, Liability-Based Fee-Shifting Rules and Settlement Mechanisms Under Incomplete Information, 71 CHI.-KENT L. REV. 461 (1995).

${ }^{101}$ Rosenberg \& Shavell, supra note 98, at 6-7.

${ }^{102} I d$.

${ }^{103}$ See id. at 7-8 (detailing proofs regarding a plaintiff's incentive to sue). 
total award. ${ }^{104}$ I label this a "Category 2" suit. In either category, the defendant knows the plaintiff's case is without merit, but settlement is the cheapest exit strategy.

The authors conclude that (1) a plaintiff's filing expense is usually minimal; (2) the courts are only able to weed out patently frivolous claims, thus not controlling the initial quality of claims; (3) a plaintiff may prevail without inquiry if unchallenged by the defendant; and (4) the defendant often has greater litigation costs in gathering evidence than the plaintiff has in filing a claim. ${ }^{105}$ This model, therefore, demonstrates the prior work of Steven Shavell: ${ }^{106}$ it provides one instance in which the low private costs of initiating a suit are dangerously below that of the total cost to the public.

Framework 2 predicts that plaintiffs without a viable case may still find it profitable to sue. ${ }^{107}$ However, it may be somewhat unrealistic to assume that the defendant's initial response cost is necessarily high: filing a motion for summary judgment, for example, may actually be inexpensive. A Category 1 suit may only result in a very small payout to the plaintiff. In fact, critics have noted that Rosenberg and Shavell's model "can only explain nuisance suits that settle for very small amounts." ${ }^{108}$ In addition, a Category 2 suit might not be feasible at all: how can a nonviable suit have a significant probability of a large award? This possibility seems to rely primarily on the arbitrariness and "generosity" of juries.

Lucian Bebchuk has helped explain these difficulties with Rosenberg and Shavell's model. ${ }^{109}$ Bebchuk's model focuses on negative-expected-value (NEV) suits in which the plaintiff's expected litigation costs exceed the expected award. In his model, these suits may or may not have merit-suits with small awards but a high probability of

${ }^{104}$ See id. at 7 (" [If] the plaintiff would be willing to engage in litigation, then he can obtain from the defendant not only his defense costs, ... but also his expected loss.").

${ }^{105} I d$. at $9-10$.

${ }^{106}$ See supra text accompanying notes 37-43 (describing Shavell's work).

${ }^{107}$ Rosenberg \& Shavell, supra note 98 , at 9.

108 Amy Farmer \& Paul Pecorino, A Reputation for Being a Nuisance: Frivolous Lawsuits and Fee Shifting in a Repeated Play Game, 18 INT'L REV. L. \& ECON. 147, 148 (1998) (citing Avery Katz, The Effect of Frivolous Lawsuits on the Settlement of Litigation, 10 INT'L REV. L. \& ECON. 3, 4 (1990)).

${ }^{109}$ Lucian Arye Bebchuk, A New Theory Concerning the Credibility and Success of Threats to Sue, 25 J. LeGAL STUD. 1 (1996). 
winning could still be NEV suits. ${ }^{110}$ Bebchuk notes that Rosenberg and Shavell's model is only applicable when the defendant incurs large up-front costs before the plaintiff incurs substantial costs. ${ }^{111}$ Thus, if it is inexpensive to engage in pre-trial dismissal procedures, Rosenberg and Shavell's model will not accurately predict the defendant's behavior-the defendant will litigate rather than settle, and the plaintiff cannot extract payment for filing. Furthermore, Bebchuk predicts that the plaintiff's extracted payment in an NEV suit will be just below the defendant's cost of response, regardless of the expected judgment. ${ }^{112}$ This is similar to Rosenberg and Shavell's prediction for a Category 1 suit. $^{113}$

However, Bebchuk argues that even if the plaintiff cannot force the defendant to incur large up-front litigation costs, she might still create a credible threat to induce settlement. ${ }^{114}$ Bebchuk reconceptualizes the litigation process such that litigation costs are spread out over time and bargaining takes place throughout the litigation process. ${ }^{115}$ Bebchuk reasons that the plaintiff might have a more credible threat later in the process, when she only has a small fraction of her litigation costs remaining; the defendant and plaintiff are aware of this potential threat. ${ }^{116}$ Thus, this model predicts that the defendant might settle for an amount greater than her expected initial costs, by accounting for a potential settlement amount that a plaintiff might extract later in the process. ${ }^{117}$ This fear can make even a small-stakes nuisance suit potentially credible at the start. ${ }^{118}$

Turning back to Rosenberg and Shavell's model, if a plaintiff is able to disregard her sunk costs later in the negotiation process, she will be slotted into Category 2 where the expected award exceeds the expected cost. This bumps the defendant's offered settlement

${ }^{110}$ See Farmer \& Pecorino, supra note 108, at 148 (explaining that "Bebchuk is not considering nuisance suits per se"). Thus, Category 1 lawsuits of Rosenberg and Shavell's model are both nuisance suits and NEV suits.

${ }^{111}$ Bebchuk, supra note 109, at 3.

${ }^{112}$ Id. at 17.

${ }^{113}$ See supra text accompanying note 101.

${ }^{114}$ See id. at 4 (maintaining that when negotiations reach the stage where only a small fraction of litigation costs remain, a plaintiff's threat may seem more credible).

${ }^{115}$ See id. (focusing on the "divisibility" of litigation costs).

${ }^{116} I d$.

${ }^{117}$ See id. at 7 ("The settlement amount agreed upon at the initial round will be shaped by the parties' costs at the first stage and by the settlement amount that is expected to be agreed on if the parties were to reach the second bargaining round.").

${ }^{118}$ See id. at 4, 6-9 (analyzing how the divisibility of litigation costs and continuous bargaining increases plaintiffs' bargaining power and changes player strategies). 
amount up to at least her expected costs plus the probable award. ${ }^{119}$ Thus, even if the case starts as a Category 1 suit, ${ }^{120}$ if the plaintiff reevaluates her case and disregards her sunk costs, she might continue to pose a threat to the defendant. As a result, the plaintiff could extract a higher settlement amount, somewhere between that predicted by Rosenberg and Shavell in Categories 1 and 2. Bebchuk concludes that "plaintiffs have credible threats in a much wider set of casesincluding in numerous small-stakes cases-than has been suggested by prior economic analysis of the subject."121

The defendant's awareness of a possible second plaintiff will dramatically change her costs and benefits to settling. Thus, in order to compare these nuisance suit models to the pro-openness models of Framework 1, we must incorporate the idea of a second plaintiff and a repeat defendant. ${ }^{122}$

Thomas Miceli predicts that a repeat defendant's strategy will depend on her perception of the fraction of viable suits. ${ }^{123}$ Miceli's model is based on the assumption that all truly injured plaintiffs have positive-expected-value (PEV) suits while uninjured plaintiffs have only NEV suits. ${ }^{124}$ In his proof, he establishes that, if the fraction of truly injured plaintiffs is high, the defendant will prefer to settle all cases because settling is cheaper than pursuing litigation. ${ }^{125}$ But, across-the-board settlement creates a positive return for all plaintiffs

${ }^{119}$ Rosenberg \& Shavell, supra note 98 , at 7.

${ }^{120}$ In a Category 1 suit, the defendant's offered settlement would be just under her expected initial costs of response. See supra text accompanying notes 101-03 (describing expected settlements in Category 1 suits).

${ }^{121}$ Bebchuk, supra note 12, at 1. Patricia Danzon, a noted scholar in medical malpractice, affirms this conclusion. She states that "the plaintiff can increase the maximum a rational defendant would offer by increasing the latter's expected costs, and conversely the defendant can decrease the minimum the plaintiff would settle for and increase the likelihood of his dropping the case by increasing his costs of proceeding." DANZON, supra note 38, at 192.

${ }^{122}$ Note that both of these models exclude the problem of repeat play and the precedential effects of settling or litigating.

${ }^{123}$ See Thomas J. Miceli, Optimal Deterrence of Nuisance Suits by Repeat Defendants, 13 INT'L REV. L. \& ECON. 135, 142 (1993) (explaining that the probability that a defendant will litigate "decreases as the fraction of legitimate suits in the population increases").

${ }^{124}$ See id. at 136 (assuming that a truly injured plaintiff has a probability of winning greater than zero, while an uninjured plaintiff has a probability of winning of zero, though both have costs of filing and trial). This contrasts with Rosenberg and Shavell's description of a Category 2 suit, and also with Bebchuk's theory. See Rosenberg \& Shavell, supra note 98, at 7-8; Bebchuk, supra note 109, at 4.

${ }^{125}$ Miceli, supra note 123, at 136. 
who file suit, and thus both injured and uninjured plaintiffs will have incentive to file. ${ }^{126}$

This misplaced incentive leads to a defendant's "equilibrium strategy": settling just frequently enough to save costs, but infrequently enough to make nuisance suits unprofitable. ${ }^{127}$ Equilibrium in the defendant's strategy is achieved by balancing the "temptation" of immediate cost-savings through settlement with the necessary "enforcement" technique of occasionally litigating to prevent spawning nuisance lawsuits. ${ }^{128}$ As the fraction of legitimate suits increases, temptation will begin to override enforcement tendencies. ${ }^{129}$ But if the defendant establishes a reputation for settling, she may encourage rogue plaintiffs with meritless claims to attempt to extract settlement. A significant conclusion from Miceli's model is, therefore, that the plaintiff's behavior is conditional upon the defendant's settlement history. And, as a result, the defendant must tailor her strategy to accommodate the predicted reactions of potential plaintiffs.

It is also interesting to note that some scholars have developed the concept of a repeat plaintiff. As it is difficult to imagine a repeat plaintiff with consistent injuries, Farmer and Pecorino have developed a model where the repeat plaintiff's lawyer may be able to establish a credible threat in a nuisance suit from the lawyer's own reputation of refusing to settle. ${ }^{130}$ In addition, since the attorney is threatening to fully litigate to a verdict, the plaintiff can extract a settlement amount that approaches the defendant's full costs of going to trial, a greater amount than initially predicted by Rosenberg and Shavell. ${ }^{131}$ Farmer

126 Id.

127 Id. at 137. According to some accounts, cigarette makers draw out litigation in order to absorb a plaintiff's time and money and set a formidable precedent: the tobacco industry has not paid any damages to private litigants in over forty-three years and 800 suits. See, e.g., Garth Alexander, Up In Smoke, Sunday TimeS (U.K.), Mar. 17, 1996, Bus. Focus, at 3 (describing the tobacco industry's forty-year united front against litigants); Mark Curriden, Tobacco Industry Lawsuit Becoming Endurance Test, DALLAS MORNING NEWS, Feb. 23, 1997, at 1A (asserting that the tobacco industry is expert at taking punches and using up the adversary's money).

${ }_{128}$ Miceli, supra note 123 , at 138-39.

129 See id. at 140 ("A higher fraction of legitimate suits . . both increases the defendant's temptation to deviate from his threat, since the savings from avoiding trial are larger, and reduces enforcement, since the number of deterrable suits is lower.").

${ }^{130}$ See Farmer \& Pecorino, supra note 108, at 150 (indicating that a defendant will consider opposing counsel's reputation in deciding whether to settle).

${ }^{131}$ See id. at 151 (speculating that a defendant will be willing to accept any settlement offer less than her likely cost of trial). This would exceed Rosenberg and Shavell's prediction that a plaintiff could extract only the initial response costs. Rosenberg and Shavell, supra note 98, at 6-7. 
and Pecorino's model further expands the number of credible nuisance suits and raises the settlement amount.

In sum, Framework 2 is based on the work of Rosenberg and Shavell, who established the groundwork for explaining nuisance suits, and other scholars, who have built models expanding the ability of nuisance suits to extract settlement amounts larger than the defendant's initial response costs alone. Framework 2 predicts that openness provides fodder for nuisance suits, which impose costs on the defendant and society without any benefit of deterrence or rightful compensation. From this perspective, there is a costly divide between a plaintiff's incentive to use the legal system and the benefits to the public from her choice to do so.

\section{Reconciling the Opposing Frameworks}

In Framework 1, an open regime alerts future plaintiffs with credible cases, thus increasing the fraction of viable suits and promoting the twin goals of tort law: compensation and deterrence. In Framework 2, an open regime alerts future plaintiffs with little likelihood of success on the merits but who are able to benefit wrongfully from learning the defendant's position. Each framework presents one side of the equation and is incomplete without the other. Comparing the assumptions and conclusions of Framework 1 and Framework 2 should provide a more complete and holistic picture of the potential costs and benefits of confidentiality of settlements.

The following table illustrates and summarizes the key premises and conclusions of the proponents of the two frameworks: ${ }^{132}$

${ }^{132}$ These papers are, obviously, complex and involve many more assumptions and conclusions than those I have listed. This table describes those relevant to the present analysis. 


\section{Framework 1: Pro-Openness}

\begin{tabular}{lll} 
Model & Key Premise & Conclusion \\
\hline \hline $\begin{array}{l}\text { Daughety and } \\
\text { Reinganum, } \\
\text { Hush Money }\end{array}$ & $\begin{array}{l}\text { Future plaintiffs are } \\
\text { initially ignorant; they } \\
\text { rely on the disposi- } \\
\text { tion of Pl's case to } \\
\text { inform them about } \\
\text { the merits of their } \\
\text { own cases. }\end{array}$ & $\begin{array}{l}\text { Open trial provides more } \\
\text { publicity and information } \\
\text { than an open settlement, } \\
\text { which in turn provides } \\
\text { more than a confidential } \\
\text { settlement would. }\end{array}$ \\
\hline $\begin{array}{l}\text { Daughety and } \\
\text { Reinganum, } \\
\text { Secrecy and Safety }\end{array}$ & $\begin{array}{l}\text { Plaintiffs cannot re- } \\
\text { cover in nonviable } \\
\text { suits; they are able to } \\
\text { recover only if the de- } \\
\text { fendant is culpable } \\
\text { and caused their in- } \\
\text { jury. }\end{array}$ & $\begin{array}{l}\text { Greater publicity informs } \\
\text { more injured plaintiffs, in- } \\
\text { creasing the fraction of vi- } \\
\text { able suits and compensa- } \\
\text { tion. }\end{array}$ \\
&
\end{tabular}

\section{Framework 2: Pro-Confidentiality}

Model

Rosenberg and Shavell

\section{Key Premise}

Plaintiffs and defendants have mutual knowledge of parties' costs and likelihood of success.

Bebchuk; Farmer and Pecorino

\section{Plaintiff is able to es-} tablish a credible threat later in the litigation process, even if not initially; or plaintiff's lawyer can establish credible threat through reputation.

$\begin{array}{ll}\text { Miceli } & \text { Repeat defendants } \\ & \text { have an optimal strat- } \\ & \text { egy of response in } \\ & \text { order to reduce pre- } \\ & \text { sent costs and deter } \\ & \text { future suits. }\end{array}$

\section{Conclusion}

Plaintiffs can recover on nonviable suits by extracting the defendant's initial costs of response.

Plaintiffs can recover on nonviable suits for amounts greater than the defendants' initial costs of response.

\author{
Settlement is optimal if \\ there is a high fraction of \\ viable suits; however, a \\ reputation for settlement \\ may encourage frivolous \\ suits.
}


The pro-confidentiality and pro-openness frameworks share some of the same assumptions. In the pro-openness framework, plaintiffs are at least partially dependent on signals and information from prior cases against the defendant. ${ }^{133}$ In the pro-confidentiality framework, plaintiffs are knowledgeable about the merits and costs of their own case but use signals from prior lawsuits to evaluate defendant's strategy and ultimately decide whether to sue. ${ }^{134}$ Thus, the behavior of future plaintiffs is conditional upon a defendant's decision to litigate or settle. The difference in the frameworks is fundamentally based upon which plaintiffs are able to prevail after reading the signals: Daughety and Reinganum assume that only truly injured plaintiffs will succeed, while Rosenberg and Shavell's models demonstrate the possible success of nonviable suits.

Assuming that nonviable suits can indeed succeed, our goal should be to provide incentives that will reduce the number of frivolous plaintiffs while facilitating the claims of truly injured plaintiffs. In other words, we want to create incentives that align as closely as possible to the social costs and benefits of each suit. ${ }^{135}$

From the above table, I have derived several Rules:

\section{Rule 1: Future Plaintiffs' Decisions to Sue Are Partially Conditional Upon a Defendant's Past Decisions to Litigate, Settle Openly, or Settle Confidentially}

Rule 1 is derived from a combination of Daughety and Reinganum's work with Miceli's. Daughety and Reinganum conclude that the information provided by litigation or an open settlement helps future plaintiffs form their cases; Miceli concludes that a defendant's litigation strategy may affect future litigants' decisions to file a claim initially and whether to settle or litigate once the claim is filed.

${ }^{133}$ See Daughety \& Reinganum, Hush Money, supra note 77, at 663 (“[A]ssuming that some potential plaintiffs do not know they have a case, and that the disposition of a previous case can affect whether or not later plaintiffs file suit.”).

${ }^{134}$ See Miceli, supra note 123, at 137 (assuming that plaintiffs will adopt a strategy dependent on the defendant's settlement strategy).

${ }^{135}$ See supra text accompanying notes 35-41 (discussing the myriad costs, benefits, and incentives that may factor into a plaintiff's decision to litigate, which often diverge from society's interests). 
Rule 2: Future Plaintiffs Receive One or More Types of Information from a Defendant's Action: A Strategy Signal and/or Information Relevant to Culpability

Rule 2 is derived from combining the pro-openness framework with the pro-confidentiality framework. The pro-openness framework concludes that the information provided by settlements to future plaintiffs increases just compensation. This is because future plaintiffs learn evidentiary information about their case. However, the proconfidentiality framework establishes that nuisance suits can succeed, and that a defendant's decision to settle or litigate may affect other plaintiffs' decisions to litigate. These frameworks indicate, therefore, that there are actually two types of information at issue: information about culpability and information about the defendant's litigation strategy.

Rule 3: In Settlements, Strategy Signals Are Likely to Encourage Frivolous Lawsuits; Information Relevant to Culpability Is Likely to Increase Meritorious Suits

Rule 3 simply sorts the effects of the two types of information in Rule 2. Rule 3 will effectively inform plaintiffs about how to proceed with their own litigation. Strategy signals are at least somewhat useful to all plaintiffs, whether their claims are meritorious or not. However, a mere strategy signal will not provide actual facts or case-specific information that would allow a future plaintiff to formulate a claim or gather evidence. Culpability information is far more useful to a meritorious plaintiff because it has evidentiary value in proving her case. On the other hand, culpability information is considerably less useful to plaintiffs with frivolous claims, since they are more likely to try to extract a quick initial settlement (as opposed to proceeding with litigation). Even if the culpability information might help the frivolous plaintiff establish a more credible threat, the strategy signal would be far more useful because it would indicate how the defendant could be expected to act in settlement negotiations.

The Rules point to the crux of the problem: all signals are not created equal. The type of information provided by the signal creates different incentives for different plaintiffs. Daughety and Reinganum implicitly acknowledge the variation in signal types by their range of 
publicity quantity. ${ }^{136}$ I believe there is an additional level of variation: the open settlement itself may have a range of different information types. An open settlement may provide useful facts about the incident, or it may indicate only that the defendant is willing to settle for a certain amount. The first may encourage injured plaintiffs to obtain rightful compensation, while the second might incentivize frivolous suits.

Rule 3 sorts signals into two categories. "Quantitative" signals are those that indicate facts about whether and how the defendant settled. "Qualitative" signals are those that provide information about the allegations, circumstances, and culpability of the defendant. For example, assume a defendant settled with a plaintiff, $P 1$, who alleged that the defendant's dumping of toxic chemicals into a lake caused her daughter's rare form of cancer. The settlement agreement will contain factual allegations as well as a settlement amount. Specific information about the allegations (e.g., the timing of dumping, the type of disease contracted, the method of contraction, the chemical dumped) will help others in assessing whether the defendant's actions injured them as well. Such information would help those potential future plaintiffs to establish whether the defendant's culpability for PI's injury correlates with their own cases. This information is a qualitative signal. Information about the actual settlement amount (e.g., defendant paid $P 1 \$ 1$ million) only informs the public about the defendant's strategy; it may convey some information about the defendant's culpability in that case, but it primarily encourages future plaintiffs to formulate demands that they may not otherwise have formulated. This information is a quantitative signal.

A fully confidential settlement provides essentially no signal. An open settlement, however, may contain quantitative signals, qualitative signals, or both. It follows that all open settlements are not equal in terms of costs or benefits. I predict that open settlements' societal costs and benefits depend on the extent to which the signals contained in those settlements are qualitative or quantitative. Lawmakers can sort meritorious suits from nonviable suits by carefully crafting laws that are sensitive to the particular incentives provided by a settlement's type of openness.

For example, if our goal is to maximize legitimate compensation while deterring frivolous suits, we can predict which types of "sun-

${ }^{136}$ See supra text accompanying notes 79-82 (describing how litigation and open settlements provide more information than closed settlements). 
shine" reforms will be most effective in meeting these joint goals. Across-the-board sunshine regimes will provide uniform openness, at the cost of encouraging frivolous lawsuits; blanket confidentiality will prevent just compensation. Alternatively, sunshine regimes tailored to specific areas where the public interest is especially great will likely be the most efficient. Even then, the type of "sunshine" is still critical. In order to inform an injured $P 2$ about a defendant's culpability, we should ensure that the signal given is as qualitative as possible.

There is obviously no clear line dividing the effects of a qualitative signal from those of a quantitative signal. A truly injured plaintiff who receives only quantitative signals might still be encouraged to sue, while a frivolous plaintiff might initiate a nuisance suit based solely on qualitative signals. ${ }^{137}$ However, a quantitative signal about the amount of settlement is generally less useful to a meritorious plaintiff, while a frivolous plaintiff could find the amount of a past settlement very important in formulating her future demands. ${ }^{138}$

Very large settlements could be one exception to this generalization. Learning that the defendant recently made a massive settlement or payment to a previous plaintiff might suggest that the defendant was guilty of what the prior plaintiff alleged; of course, it may not necessarily indicate that the defendant is responsible for the potential plaintiff's injury. Furthermore, certain defendants may value settlement very highly and pay out large sums to avoid steep litigation costs. Regardless, unusual settlement amounts may indicate more than just strategy on the defendant's part.

Generally, sunshine regimes that publish only the quantitative aspects of a settlement will be especially prone to encouraging frivolous lawsuits and, compared to regimes that publish qualitative signals, will not provide society with as much information useful in preventing potential danger. In short, quantitative signals are more likely to produce public costs without increasing public benefit. Furthermore, regimes that publish the amount of settlement seem doubly dubious: if the plaintiff knows how much the defendant is "good for," she has greater insight into the defendant's strategy. Conversely, although

137 See DANZON, supra note 38, at 192 ("In practice there is no clear distinction between legal actions that generate information and promote more accurate deterrence, and those that serve purely strategic purposes.").

${ }^{138}$ Rosenberg and Shavell assume that a plaintiff and defendant jointly know the costs of litigation. Rosenberg \& Shavell, supra note 98, at 6 . If the plaintiff did not know this information, however, learning the amount of a prior settlement would be a powerful indicator of the defendant's costs of litigation and future settlement amount. 
qualitative signals might encourage some costs, they are far more likely to encourage the public benefits of deterrence and just compensation. As a result, we can hope to maximize public benefits and minimize overall costs by tailoring the sunshine laws to provide qualitative signals in the fields and industries where the public has the greatest interest due to health, safety, and welfare concerns.

\section{A PRACTICAL ILLUSTRATION: MEDiCAL MALPRACTICE SETTLEMENTS}

As sunshine regimes become more prevalent across the country, predictions about the costs and benefits of confidential settlements become more relevant and pressing. As noted in Part II.C, a statutory solution is likely the best approach to restrict confidential settlements because it would not be as prone to uneven judicial application as a procedural rule permitting case-by-case judicial discretion. In addition, a statutory solution can be more precise: it can target those industries in which the public has the greatest interest in requiring openness.

This Comment calls for tailoring the openness movement in two ways. First, the legislature should target a program of mandatory openness by field or industry. Certain industries, such as pharmaceutical producers, automotive makers, and healthcare providers require greater state or federal legislative restrictions on confidential settlements due to the potential for public hazard. On the other hand, private contractual disputes that do not directly implicate public health or safety concerns should be free to settle confidentially. In other words, parties deserve contractual autonomy unless the public or legislatures conclude that openness is required in a particular realm in order to further public safety. Second, the legislature should craft sunshine laws to promote qualitative signals about the defendant's culpability in order to increase the societal benefit. Meanwhile, legislators should be wary of promoting quantitative signals and should be cognizant of the risk of increasing frivolous lawsuits.

In the absence of legislative solutions, some courts have taken dramatic steps. For example, the District of South Carolina recently enacted a local rule strictly prohibiting a judge from placing a settlement agreement under seal. ${ }^{139}$ This approach is a blunt, across-the-board

${ }^{139}$ DIST. S.C. CIV. R. 5.03(E) ("No settlement agreement filed with the Court shall be sealed ...."). Rule 5.03 is significantly harsher than most other district court local rules, which bar secret settlements only where the public interest or safety is at issue. 
sunshine rule. The District of South Carolina is justifiably frustrated by judges who seem unable to effectively restrict confidential settlements between parties. However, a complete prohibition of confidential settlements is not the right approach, nor is it appropriate for the judiciary to make such a decision. According to the above discussion, this policy will not be efficient because it fails on both fronts: first, it applies indiscriminately to any settlement, regardless of the type of lawsuit; and second, it treats all types of information the same. As a result, it will facilitate compensation but simultaneously encourage frivolous lawsuits.

Other states, however, have adopted a more tailored approach through legislative regulation of targeted industries. For example, some states restrict the confidentiality of medical malpractice settlements without outlawing secret settlements altogether. These states have created a disclosure system which publishes medical malpractice histories of physicians, attempting to provide information to healthcare consumers. This approach, aside from being much more targeted, is different from the District of South Carolina's approach in that it does not prohibit secrecy but actually mandates open publication. These states have already tailored their legislation by industry, and therefore are heading in the right direction. However, the manner and method of publication (i.e., what information is actually published) will determine what sort of signals these laws will provide to future litigants.

In order to facilitate the practical application of the Rules that I have described above, I will outline sunshine laws in the medical malpractice area and proceed to analyze the signals created by these laws. In doing so, I hope to illuminate the manner in which my proposed Rules can help direct legislatures to the appropriate statutory action.

\section{A. Background and the Federal Requirements}

Congress passed the Health Care Quality Improvement Act of 1986 (HCQIA) in order to create a federal data bank of medical mal-

\footnotetext{
See supra text accompanying notes 45-46. Chief Judge Joseph Anderson, Jr., of the District of South Carolina, supports Rule 5.03's restriction on secret settlements, in particular because it prevents judges from balancing docket pressures against the public's need for information. See Anderson, supra note 48, at 729 ("[J]udges face incredible pressure to go along with court-ordered secrecy in the heat of battle.”); $c f$. Toal \& Riley, supra note 17, at 768-70 (describing and defending South Carolina's civil procedure rule, S.C. R. CIV. P. 41.1, which generally favors sunshine and openness).
} 
practice settlements. ${ }^{140}$ The resulting data bank, which hospitals are required to access before hiring any prospective doctor, provides information on each physician. ${ }^{141}$ The data bank's information is available to state licensing boards as well. ${ }^{142}$ Information collected through the HCQIA is confidential; unless otherwise provided by state law, it may only be disclosed to the physician or practitioner involved or for "professional review activity."

This exact provision became the central issue last June in Medical Society of New Jersey v. Mottola, in the U.S. District Court in New Jersey. ${ }^{144}$ In Mottola, the plaintiffs contested a New Jersey statute that allowed disclosure of all medical malpractice judgments and settlements. ${ }^{145}$ The New Jersey Health Care Consumer Information Act (NJHCCIA) required medical malpractice settlements to be published. ${ }^{146}$ Under the NJHCCIA, "[a]ll medical malpractice court judgments and all medical malpractice arbitration awards reported to the applicable board, in which a payment has been awarded to the complaining party during the most recent five years, and all settlements of medical malpractice claims reported to the board" should be published, including settlements reached prior to the law's enact-

${ }^{140} 42$ U.S.C. $\$ \S 11101-11152$ (2000). According to the HCQIA, any insurance entity which makes a payment in settlement or in order to satisfy a judgment is subject to its reporting requirements. Id. $\S 11131(\mathrm{a})$. The insurance agency must provide the name of the physician or health care practitioner, the amount of payment, the name of the hospital affiliated with the physician or health care provider, a description of the actions upon which the claim was based, and any other information necessary for appropriate interpretation. Id. $\$ 11131$ (b).

${ }^{141}$ Id. $\$ 11135$.

${ }^{142}$ Id. $\$ 11137(\mathrm{a})$.

${ }^{143} I d . \$ 11137$ (b) (1). Although confidentiality is presumed, the HCQIA leaves open a potential avenue of publicity: "Nothing in this subsection shall prevent the disclosure of such information by a party which is otherwise authorized, under applicable State law, to make such disclosure." Id.

${ }^{144} 320$ F. Supp. 2d 254 (D.N.J. 2004).

${ }^{145} I d$. at 261. The plaintiffs in Mottola claimed, inter alia, that their "right to privacy, secured to them under federal law, namely the HCQIA, would be deprived under color of state law" if such information were published. Id. at 264. The plaintiffs also made various claims alleging that the law violated their constitutional rights. Id. at 27173.

${ }^{146}$ N.J. STAT. ANN. § 45:9-22.22 (West 2004). New Jersey has had reporting requirements similar to the HCQIA in place since 1983, although the content of the reporting under such laws has been confidential. See Mottola, 320 F. Supp. 2d at 259-60 (acknowledging that N.J. STAT. ANN. § 17:30D-17 (West 1994), passed in 1983, requires a Medical Practitioner Review Panel to maintain malpractice settlement records that are protected by the confidentiality provisions of N.J. STAT. ANN. $\S 8$ 45:9-19.3 and 45:919.10 (c) (West 2004)). 
ment. ${ }^{147}$ The court upheld the statute, concluding that " $[\mathrm{t}]$ here is no provision in the HCQIA that makes information independently collected by a state agency confidential." ${ }^{148}$ Furthermore, the HCQIA condones New Jersey's law by allowing for state disclosure. ${ }^{149}$

\section{B. The Complexity of Medical Malpractice Settlements: Does a Settlement Amount Convey Culpability?}

The Mottola court assumed that the NJHCCIA was in the public interest because "providing consumers with relevant information about physicians' backgrounds helps consumers to make informed choices with regard to medical services." 150 In addition, malpractice litigation serves an important function in compensating victims of poor care, disciplining negligent doctors, and placing the cost of injury on insurers who pool risk and are most capable of payment. This rationale, however, is diminished by the mandatory disclaimer published along with each profile in New Jersey:

Settlement of a claim and, in particular, the dollar amount of the settlement may occur for a variety of reasons, which do not necessarily reflect negatively on the professional competence or conduct of the physician .... A payment in settlement of a medical malpractice action or claim should not be construed as creating a presumption that medical malpractice has occurred. ${ }^{151}$

${ }^{147}$ N.J. STAT. ANN. § 45:9-22.23(a) (10) (West 2004). NJHCCIA and HCQIA generally require the same reporting requirements: the Mottola court acknowledged that "insurance companies routinely comply with their State law reporting obligation by providing the [Medical Practitioner Review] Panel with a paper copy of the report that the insurance carrier submits to the Data Bank, pursuant to the HCQIA." Mottola, 320 F. Supp. 2d at 260 (citation omitted). The very same information, however, is not confidential once submitted under the NJHCCIA.

${ }^{148}$ Mottola, 320 F. Supp. 2d at 270. Thus, even if the information submitted is exactly the same, as long as the insurers submit the information separately to the New Jersey Medical Practitioner Review Panel (not through the federal Data Bank), the HCQIA's confidentiality provisions do not apply. Id. The court declined to address whether the retroactivity of the NJHCCIA violated the physicians' expectation of privacy. Id. at $270-71$.

14942 U.S.C. $\$ 11137$ (b) (1) (2000).

${ }^{150}$ Mottola, 320 F. Supp. 2d at 272.

${ }^{151}$ N.J. STAT. ANN. \$ 45:9-22.23(a) (10)(d) (West 2004). Other states that publish physician profiles have similar disclaimers. See, e.g.,; IDAHO CODE ANN. § 544603(1) (o) (iii) (2003) (adding a comparable disclaimer to the state's malpractice reporting requirements); MASS. ANN. LAWS ch. 112, § 5 (LexisNexis 2004) (mandating reporting of all malpractice settlements to a review board accompanied by a similar disclaimer). 
If a settlement amount does not "necessarily reflect negatively on the professional competence or conduct of the physician," how does it provide the public "relevant" information? The central question, therefore, is whether settlement information conveys useful information to the public: does a settlement indicate that the doctor who settled was negligent or incompetent?

From the outset, publishing the amount of a settlement appears to be a quantitative signal. Of course, there may be some way that it still conveys important qualitative information about the doctor's competence. First, if settlements indicate incompetence, one would assume that medical malpractice insurers would increase premiums for doctors who have settled prior claims. This does indeed occur, but to a much smaller degree than one would expect. In general, doctors' medical malpractice rates are far more dependent upon their specialty than their personal history: riskier specialties are prone to more lawsuits and thus carry higher premiums. ${ }^{152}$ In addition, one would expect a doctor with a poor record to be paying much higher rates than one without any claims against her. Though recent crises in the malpractice industry have made insurers much more sensitive to a doctor's claim history, this has not always been the case. ${ }^{153}$ Insurers

${ }^{152}$ Specialty makes a far greater impact on premium rates than the type of practice, age of physician, or location of practice. Data from the American Medical Association show that self-employed physicians who specialize in obstetrics and gynecology or surgery have premiums between three and four times greater than that of a general family practitioner. AM. MED. Ass'N, THE Guide to MEDiCAL ProfESSIONAL LiABiLity INSURANCE 127 (1991); see also DANZON, supra note 38, at 95 (concluding that rating structures have changed to include "more variation in specialty differentials among states"); Richard Zeckhauser \& Albert L. Nichols, Lessons from the Economics of Safety, in ECONOMICS OF MEDICAL MALPRACTICE 19, 23 (Simon Rottenberg ed., 1978) (noting that most malpractice insurance policies "base the premium solely on the physician's specialty, and not on his past record of malpractices suits"). Settlements may not even be reflective of the doctor's personal performance, but instead reflective of an entire department or hospital. See Mary Jo Layton et al., Doctors' Insurers Paid \$1B in 5 Years: Judge Orders Release of Malpractice Data, RECORD (Hackensack, N.J.), June 9, 2004, at A1 (relating a department chair's fear that his position makes him appear responsible for lawsuits in his department in which he played no direct role); Jennifer Silverman, Confidential Settlements: New Jersey To Open Physician Malpractice Records, OB/GYN NEws, Mar. 14, 2004, at 30 (discussing the factors involved in the insurer's decision to settle, and concluding that the decision to settle does not necessarily reflect poor care on the part of the doctor).

${ }^{153}$ See DANZON, supra note 38, at 94-95 (finding that there has been "very little rating on the basis of individual exposure or experience" since 1975, so that "individual surcharges are applied to no more than [one] to [two] percent of physicians"). But see Michelle M. Mello, The New Medical Malpractice Crisis, 348 NEw EnG. J. MED. 2281, 2282 (2003) (stating that some insurers will no longer provide insurance to doctors with any sort of claims record); Berkeley Rice, We Settled, I Lost, MED. ECON., Oct. 8, 2004, at 49, 
have not always viewed medical malpractice suits as accurate indicators of incompetence; in fact, certain studies have shown that jury verdicts in malpractice cases reflect the victim's injury more than the doctor's culpability. ${ }^{154}$ Other studies have shown that while negligent injuries might exceed claims, the two categories do not overlap substantially: most victims of negligent care do not bring suit, and only a very small percentage of malpractice suits involve negligent care. ${ }^{155}$ Lastly, it may take a medical malpractice claim a long time to wind through the system; therefore, a recent payment might only reflect the doctor's actions many years ago.

Furthermore, medical malpractice insurers often settle with plaintiffs, and may do so over the doctor's objections. ${ }^{156}$ The insurance company may not consider lawsuits to be representative of doctors' competence, partially because the companies do not allow the doctor to defend herself. ${ }^{157}$ Moreover, a doctor might settle cases that reflect the care provided in the hospital or the department, rather than the care provided by the doctor in her individual capacity. ${ }^{158}$ Insurers might settle because it is the cheaper option, not because the doctor is actually guilty of negligence. Studies have shown that medical malpractice litigation is more costly than settlement; ${ }^{159}$ thus, insurers

50, available at http://www.memag.com/memag/article/articleDetail.jsp?id=127166 (describing a situation where an insurer cancelled a doctor's policy due to "claim and suit frequency and severity"). See generally David M. Studdert et al., Medical Malpractice, 350 NEW ENG. J. MED. 283, 283 (2004) (describing the national "crisis" of malpractice litigation).

${ }^{154}$ See, e.g., Studdert, supra note 153, at 285 (detailing the "disconnections observed between injury and litigation").

${ }^{155} I d$.

${ }^{156}$ Different insurers treat medical malpractice claims differently. See, e.g., AM. MED. Ass'N, supra note 152, at 113 (noting that some insurers may not settle without the physician's consent but that others retain total control over the decision to settle); see also Rice, supra note 153, at 49 (describing the negative outcomes emanating from a forced settlement by a doctor who did not want to settle due to the stigma of settlement as an admission of guilt).

${ }^{157}$ Settlement decisions are obviously complex. The AMA notes that some considerations to be weighed are "whether liability is obvious, whether the plaintiff is a very sympathetic character, and whether one or more of the physician defendant(s) is likely to be a poor witness." AM. MED. Ass'N, supra note 152, at 107.

158 See Layton, supra note 152, at A1 (discussing an obstetrician's settlement of three claims as a director of the hospital perinatal high-risk unit).

${ }^{159}$ Ninety percent of all medical malpractice cases are settled out of court. DANZON, supra note 38 , at 31 . Previous studies have found that a plaintiff is twice as likely to receive payment through settlement than through litigation. See id. (finding that plaintiffs win one in four medical malpractice cases litigated, but half of all plaintiffs who settle out of court receive some payment). This statistic appears to vindicate Rosenberg, Shavell, and Bebchuk's predictions that a plaintiff who would not succeed 
might be settling cases for financial reasons, regardless of culpability, further bolstering the claim that settlement amounts do not reflect care quality. However, this strategy could be costly: according to Miceli, the insurers' strategy of repeat settlement will be efficient only if the number of suits does not rise beyond a critical point. ${ }^{160}$

Supporters of mandatory publication of settlement agreements might argue that even if settlements do not reflect physician competence (and are not useful tools for the consumer), they effectively deter physician misconduct through the mere publication of data. Physician licensing boards have been notoriously ineffectual in disciplining incompetent physicians. ${ }^{161}$ Thus, it is possible that the mandatory publication of all settlement amounts provides muchneeded deterrence. ${ }^{162}$ Since doctors' premiums may not rise with additional lawsuits, insurers are effectively insulating doctors from some of the financial cost of negligence; accordingly, an additional method of deterrence is necessary. ${ }^{163}$ Nevertheless, it does not seem likely that

at trial may still extract payment. See Rosenberg \& Shavell, supra note 98, at 3; Bebchuk, supra note 109 , at 4 . It should be noted that post-verdict awards are generally much higher than out-of-court settlements. DANZON, supra note 38 , at 31 .

${ }^{160}$ See supra text accompanying notes 123-29 (discussing Miceli's model of party behavior).

${ }^{161}$ See, e.g., Arthur Kane \& Allison Sherry, Buried Mistakes, Denver Post, Mar. 7, 2004, at 1A (revealing the Colorado Board of Medical Examiner's inability to hold physicians accountable for negligence); Tony Leys, Mercy Ordered to Pay \$3 Million in Lawsuit, Des MoINes REg., July 16, 2004, at 1A (describing a situation where a hospital allowed a negligent doctor to continue practicing even though the Iowa Board of Medical Examiners had ordered him to quit); Opinion, Right To Know: Patients Deserve to Know Doctors' Histories, RECORD (Bergen County, N.J.), May 10, 2004, at L6 (citing an investigation that found that the few doctors in New Jersey with multiple malpractice claims and settlements had never been punished by the Board of Medical Examiners); Walsh \& Weiser, Secret Filing, Settlement Hide Surgeon's Record, supra note 1 (revealing the ineffectiveness of hospitals' physician-review systems). Of course, licensing boards may view the settlements as poor indicators of care quality, just as insurers do.

${ }^{162}$ See Steven Shavell, Theoretical Issues in Medical Malpractice, in ECONOMICS OF MEDICAL MALPRACTICE, supra note 152, at 35, 44 (noting that society has to resort to nonmarket institutions to guarantee physician care quality when patients are unable to adequately judge medical service quality).

${ }^{163}$ See id. at 40-43 (discussing the moral hazard problem where insurance reduces the physicians' incentives to avoid loss); Zeckhauser \& Nichols, supra note 152, at 30 (finding that premiums must reflect the claims record of individual providers in order to create meaningful financial incentives for physicians). Some scholars believe that each plaintiff's compensation should derive from her own estimate of risk (through insurance), rather than the doctor's negligence, suggesting that court awards are not the most efficient method of compensation. See OfFice of TeCH. Assessment, OTABP-H-119, IMPACT OF LEGAL REFORMS ON MEDICAL MALPRACTICE COSTS 47 (1993) (describing "contracting for liability" as a potential reform where patients become consumers who "structure malpractice liability to suit their own needs, balancing price and 
mere publication of settlement information will effectively deter physicians who are insured against such lawsuits. The time, energy, and frustration of litigation and settlement are probably far more valuable deterrents than publishing a physician's name in a database.

As I have argued in this Part, publication of a medical malpractice settlement amount might be only a quantitative signal that does not necessarily reflect a defendant's negligence or culpability. Thus, such publication provides more of a strategy signal to future plaintiffs, increasing nuisance suits and imposing extra costs on society. In contrast, qualitative signals provide useful information to the general public. Although qualitative signals are optimal, Mottola indicates that state courts may uphold sunshine laws that publish information containing quantitative signals to future litigants. Therefore, state legislatures need to carefully craft sunshine laws to provide qualitative information to healthcare consumers rather than mere strategy signals. If they succeed, state sunshine laws can be both just and efficient.

\section{Converting Signals from Quantitative to Qualitative Under Different State Approaches}

New Jersey is not alone in its effort to inform healthcare consumers: the Mottola court took comfort in the fact that Massachusetts had already broken ground by being the first state to publish physician malpractice histories, and several others have done so since. ${ }^{164} \mathrm{Al}-$ though these states all publish some sort of physician profile, the type of information about medical malpractice settlements provided varies from state to state. These different types of information create different signals for future plaintiffs, both quantitative and qualitative. Under Rule 3 of my analysis in Part III.C, a legislative requirement to

quality"); Shavell, supra note 162, at 55 (arguing that compensation should depend on the plaintiff's assessment of risk and injury because court awards are often inappropriately calculated and costly).

${ }^{164}$ See Med. Soc'y of N.J. v. Mottola, 320 F. Supp. 2d 254, 262 n.4 (D.N.J. 2004) (noting a "growing multi-state trend to provide citizens with better information about their physicians' backgrounds"); see also MASS. ANN. LAWS ch. $112 \S 5$ (f) (LexisNexis 2004) (setting forth profile requirements); Mark J. Greenwood, The Physician Profile Database: Publishing Malpractice Information on the Internet, 21 J. LEG. MED. 477, 492-503 (2000) (discussing the significance of Massachusetts' physician profile database, which provides an "unprecedented amount of information" to consumers). See generally CAL. BUS. \& PROF. CODE $\$ 803.1$ (2003) (setting forth profile content requirements); FLA. STAT. ANN. § 456.041 (LexisNexis 2001) (same); IdAHO CODE ANN. § 54-4603(o) (i) (2003) (same); R.I. GEN. LAwS $§ 5-37-9.2$ (a) (2) (vii) (2004); New Jersey Health Care Profile, http://www.njdoctorlist.com (follow "About the Health Care Profile" link) (last visited Oct. 22, 2005) (explaining the contents of the health care profile). 
publish settlement amounts should be tailored to provide the most qualitative information while preventing an excess of quantitative information that might induce frivolous lawsuits. An analysis of different state approaches reveals that certain approaches may be more efficient in encouraging meritorious suits and deterring frivolous suits.

As mentioned, under the NJHCCIA, the New Jersey State Board of Medical Examiners publishes the exact amount of physicians' medical malpractice awards, settlements, and judgments for five years. ${ }^{165}$ New Jersey also provides information on how many doctors in a field or practice area made medical malpractice settlements in the previous five years, to provide some context for the physician's claim history. ${ }^{166}$

Massachusetts' legislation also requires that the Medical Board of Registration create a data repository of physician profiles and make the profiles available to the public. The profile must include all medical malpractice court settlements, arbitration awards, and settlements that occurred in the previous ten years. ${ }^{167}$ Yet, instead of reporting the exact amount of settlement, it reports a doctor's settlement history as being below average, average, or above average. ${ }^{168}$ Massachusetts also lists judgment and settlement statistics for the doctor's specialty, putting a particular doctor's history into context. ${ }^{169}$ Rhode Island has recently enacted its own physician profile statute, modeled after Massachusetts and with the same requirements. ${ }^{170}$

Other states only publish information if the doctor has paid settlements exceeding a threshold level of frequency or amount. Florida's physician profile law requires that settlement payments made in

${ }^{165}$ New Jersey Health Care Consumer Information Act, N.J. STAT. ANN. § 45:922.23 (West 2004); see New Jersey Health Care Profile, supra note 164.

${ }^{166}$ See New Jersey Health Care Profile, supra note 164 (providing physician profiles, which include information about doctors' malpractice payments, and cautioning users that malpractice information should be viewed in reference to risks associated with particular fields and practice groups).

${ }^{167}$ See MASS. ANN. LaWS ch. $112 \S 5$ (f) (LexisNexis 2004) (setting forth disclosure requirements).

${ }^{168}$ See Massachusetts Board of Registration in Medicine: On-Line Physician Profile Site, http:/ / profiles.massmedboard.org/Profiles/MA-Physician-Profile-Find-Doctor.asp (last visited Oct. 22, 2005) (allowing consumers to learn about physicians' malpractice payments).

${ }^{169}$ See id. (follow "Using Physician Profiles" hyperlink; then scroll to "Malpractice Information") (indicating that profiles include malpractice payment information "within the context of the physicians' specialty").

${ }^{170}$ R.I. GEN. LAwS $§ 5-37-9.2$ (a) (2) (vii) (2004); see Wayne G. Gugliemo, Shaping Your Profile on the Web, MED. ECON., May 7, 2001, http://www.memag.com/memag/ article/articleDetail.jsp?id=118082 (noting Massachusetts' influence on Rhode Island's adoption of, and content of, online physician profiles). 
the last ten years in excess of $\$ 100,000$ be reported for medical or osteopathic doctors; those in excess of $\$ 5,000$ must be reported if the physician is a podiatrist. ${ }^{171}$ However, a bill was recently passed, although subsequently vetoed, which would have required the disclosure of all settlements for medical and osteopathic doctors, regardless of settlement amount. ${ }^{172}$ As opposed to Massachusetts, Florida publishes the exact settlement amount without any description of the claim, if the doctor's claim history exceeds the statutory threshold. ${ }^{173}$

Idaho has an approach similar to Florida's, but sets a higher bar. Under Idaho's Patient Freedom of Information Act, settlements will be disclosed if: (1) the practitioner has had five or more settlements in the most recent five years of continuous practice, each of which was $\$ 50,000$ or more; or, (2) the practitioner has had more than ten such settlements in such five-year period regardless of the amount. ${ }^{174}$ If either condition is met, all malpractice settlements during the most recent five years of continuous practice must be disclosed, except for settlements that resulted only in an adjustment in the practitioner's fee. The state publishes the date and the exact amount of the settlement. ${ }^{175}$

California combines the category-of-settlement-amount approach of Massachusetts and the threshold requirement of Idaho and Florida. ${ }^{176}$ It categorizes physicians as either high-risk or low-risk, depending on their specialty. ${ }^{177}$ The Medical Board of California will publish settlement information for low-risk physicians who have settled three or more cases within the past ten years, and for high-risk physicians who have settled four or more cases within the past ten years. ${ }^{178}$ The Medical Board of California does not publish exact settlement

${ }^{171}$ FLA. STAT. ANN. $\$ 456.041$ (LexisNexis 2001).

${ }^{172}$ See S.B. 1180, 2005 Leg., 107th Reg. Sess. (Fla. 2005) (vetoed 2005) (providing for disclosure in Florida of physician information); see also H.B. 1739, at lns.40-42, 2005 Leg., 107th Reg. Sess. (Fla. 2005) (requiring Florida profiles to reflect all information reported in the National Practitioner Data Bank).

${ }^{173}$ See Florida's Medical Quality Assurance Practitioner Profiling Page, http://www.doh.state.fl.us/mqa/Profiling/profile_search.html (last visited Oct. 22, 2005) (providing physician profile information).

174 IDAHO CODE ANN. \$ 54-4603(o) (i) (2003).

${ }^{175}$ See State of Idaho-Patient Freedom of Information Act, http:// www.idacare.org (last visited Oct. 22, 2005) (providing malpractice and settlement history to users who select a search item, choose a profile, and scroll to malpractice and settlement history).

${ }^{176}$ CAL. Bus. \& Prof. Code $\$ 803.1$ (2003).

${ }^{177} I d . \S 803.1(5)(\mathrm{b})(2)(\mathrm{A}),(5)(\mathrm{e})$.

${ }^{178} I d$. 
amounts, but describes the settlement as average, below average or above average, and includes data about the physician's length of practice and settlement statistics about doctors in the physician's specialty. ${ }^{179}$

These states' laws show two main approaches to converting a quantitative signal of a medical malpractice settlement into a qualitative signal: amount and frequency thresholds and categorization of settlement amounts. Under my analysis, both techniques would increase the amount of useful information conveyed to a future plaintiff or consumer, while possibly reducing the likelihood of frivolous claims. According to the Rules in Part III.C, settlement information can provide quantitative or qualitative signals to future plaintiffs. For all of the reasons discussed in Part IV.B, publishing the settlement amount of a medical malpractice claim alone cannot accurately signal the doctor's culpability. Consequently, disclosed settlement information should be as qualitative as possible.

There are a number of ways to provide qualitative signals. Thresholds are critical from the outset: if the majority of suits do not reflect negligence or culpability, perhaps it is not useful to publish them. Only those settlements that are above and beyond the average should be published, as they are more likely to indicate poor care quality. Additionally, if the doctor's claim history reflects significantly more claims than other doctors within her specialty, settlement information likely indicates greater culpability. Thus, settlement information would be more useful to consumers if it were published in context to similar claims or in conjunction with a doctor's history in the context of similar practitioners.

More could be done to provide qualitative signals. A short description of the claim could provide more qualitative information to a future plaintiff. As there are many possible causes for patient claims, a verbal description of the claim could be more useful than just learning about the existence of an "average" settlement. ${ }^{180}$ Regardless, an approach that simply publishes the actual settlement amount is clearly not as useful to the public, and may induce frivolous suits, because a potential plaintiff immediately knows what the doctor is "good for."

${ }^{179} I d . \S 803.1(\mathrm{~b})(2)(\mathrm{B})(\mathrm{i})$.

${ }^{180}$ In the wake of the NJHCCIA, some patient safety groups acknowledged that information about "what went wrong and why" is more useful to patients than "settlement patterns and behaviors." See Silverman, supra note 152, at 30 (relating patient advocates' recommendation that profiles disclose a summary of the case, in exclusion of the amount of the settlement). 
Medical malpractice is especially complicated because of the involvement of insurers, the high stakes of personal health and safety, and the competing interest to encourage, rather than suppress, growth in the medical industry. Generally, mandatory settlement publication, according to the model above, does not seem to further the goals of tort reform. Even though comprehensive data analysis on the effects of sunshine reforms has yet to be completed, it is clear that open settlements may vary in type and thus the incentives they provide to future plaintiffs. This Comment acknowledges the difficulty in aligning a sunshine program with litigants' incentives, but still demonstrates that a sunshine regime must be carefully tailored to align individual litigants' incentives with society's interests by reducing incentives for frivolous lawsuits while providing useful information for injured plaintiffs.

\section{CONCLUSION}

This Comment recognizes that the scholarly debate on confidentiality is disjointed because it is split between legal theorists and economists. By applying economic models' predictions of costs and benefits to the traditional discourse, several conclusions emerge.

First, it might be most effective to alter litigants' incentives rather than rely on third parties, such as judges or lawyers, to regulate litigants' actions. This can be achieved by controlling the type of information provided to potential future litigants. Careful statutory restrictions on what aspects of settlement information may be published (i.e. controlling the "signal") could be an efficient way to aid future plaintiffs while minimizing frivolous suits.

Second, assuming that neither blanket confidentiality nor total openness is optimal, some degree of open settlement is probably required. Openness is most appropriate in fields and industries that implicate the health and welfare of the general public; it may not be appropriate in fields that implicate only private concerns. As government administrative departments already regulate industries that pose significant risks to the public, it seems reasonable that regulatory agencies could also watch settlements involving widespread public hazards. Such a regime has already begun in the medical malpractice area.

Third, not all open settlements are the same. Open settlements that facilitate a transfer of information about the facts of the incident are far more useful in deterrence and compensation. In contrast, quantitative publication of settlement amounts encourages frivolous 
lawsuits, imposing costs on the public and defendants and primarily benefiting fraudulent plaintiffs. Statutory restrictions are most useful when they prohibit the disclosure of damage awards and settlement amounts, without preventing access to the critical information about a public hazard. Public disclosure of the qualitative information through the internet or watchdog organizations may be a useful complement to a regulatory regime that seeks to keep the public safe.

In sum, I have proposed that the debate over the confidentiality of settlements should be reoriented from the question of whether confidentiality is normatively good or bad, to the question of what types of confidentiality best align litigants' incentives with societal interests. The Rules and the reasoning in this Comment begin to frame that debate. 